\title{
A CRITICAL ANALYSIS OF THE INTERNATIONAL CHILD SUPPORT ENFORCEMENT PROVISIONS OF THE SOCIAL SECURITY ACT: THE (IN)ABILITY OF STATES TO ENTER INTO AGREEMENTS WITH FOREIGN NATIONS
}

\author{
Chelsea P. Ferrette
}

I. A STATUTORY ANALYSIS OF THE ICSE PROVISIONS $\ldots \ldots \ldots \quad 577$

A. The Statutory Language of the ICSE Provisions ..... 581

B. Legislative History of the ICSE Provisions ........ 586

C. Statutory Analysis of the ICSE Provisions ........ 587

II. CONSTITUTIONAL ANALYSIS OF THE ICSE PROVISIONS . . . . . 588

A. Treaty Making and State Treaty Prohibiting Clauses ... 589

B. Compact Clause ......................... 594

C. Foreign Commerce Clause .................. 597

III. UNITED STATES V. LOPEZ: IT'S EFFECT ON THE

INTERNATIONAL CHILD SUPPORT ENFORCEMENT DEBATE $\ldots 601$

IV. CAN THE ICSE PROVISIONS STAND AS AN EFFECTIVE TOOL

IN INTERNATIONAL CHILD SUPPORT ENFORCEMENT? . . . . . 604

A. The ICSE Provisions Create Legal Quagmires ....... 604

B. The ICSE Provisions Delegation of Power to States

Should be Challenged .................... 609

C. Suggested Remedies ................... 611

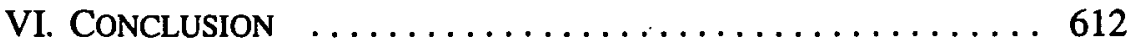

A man and a woman get married. After a number of years they have kids. A few years later, they get a divorce. The divorce decree is issued in Israel, where the wife resides, yet the ex-husband resides in Chicago. ${ }^{\prime}$ The wife obtains a claim for child support in Israel, and the husband, located in the

* Juris Doctorate Candidate, Columbus School of Law, The Catholic University of America, 2000; Candidate for Masters in International Affairs, Department of Politics, The Catholic University of America, 2000; A.B., Bowdoin College, 1994. The author wishes to thank Prof. George E. Garvey, Professor at the Columbus School of Law for his guidance and David Wamer, Attorney at the Department of Justice, Criminal Division, Office of International Affairs for his insight on this issue. Above all, the author thanks Betty P. Atkins, for her patience, care, and love, and especially use of her dining room table. Prior to publication, this paper was submitted in partial satisfaction of degree requirements at The Catholic University of America.

1. These are the facts of Nardi v. Segal, 234 N.E.2d 805 (IIl. 1968). 
United States, defaults on his child support payments. Can Illinois enforce the claim for arrears based on the Israeli divorce decree through a reciprocal agreement with Israel? Or for that matter, can Chicago deal directly with Haifa? Will an agreement between Illinois and Israel (or Chicago and Haifa) hamper the United States' foreign relations with Israel on other issues?

This case and these issues illustrate the existence of a wide gap between the need by the states to enforce international cases of child support violations and the federal government's desire to have continued comity amongst fellow nations. This gap has resulted in a federal statute allowing individual states to enter into agreements with foreign nations. Although critics have argued that some areas of international law have been promoted by state legislation, ${ }^{2}$ the International Child Support Enforcement ${ }^{3}$ (ICSE) provision of the Social Security Act is merely a band-aid to an increasingly pervasive problem. The crevice in which international child support cases exist, between the precipice of state's control over family law issues on one side and the federal government's authority over foreign affairs on the other, has become wider as more cases have fallen through the cracks and discussion has expanded on the issue. ${ }^{4}$

In examining the issue of international child support enforcement, it is necessary to notice the thin line between what is state and what is federal in nature. Although enacted laws are presumed to be constitutional, ${ }^{5}$ when the democratic process produces a law, which goes against the Constitution, the Constitution as the supreme law of the land must prevail. ${ }^{6}$

This paper examines the constitutionally of the recently promulgated statutes $^{7}$ addressing the issue of international child support enforcement. It provides an analysis of the various questions raised by the application of the provisions upon the scope of the state or local government's ability to enter in the realm of foreign affairs. Section (I) briefly examines the articulated purposes of the ICSE provisions and demonstrates that they are not consistent

2. See Richard B. Bilder, The Rolde of States and Cities in Foreign Relations, 83 Am. J. Int' l L. $821,826,828-830$ (1989) [hereinafter Bilder].

3. See 42 U.S.C.A. $\$ \S 654 \$ 32$ (A), 659a (d) (West 1998). Throughout this paper I will collectively refer to these two separate statutes as the ICSE provisions.

4. See Adair Dyer, Internationalization of Family Law, 30 U.C. DAvis L. REV. 625, 641-645 (1997)[hereinafter Dyer]; Peter H. Pfund, The Developing Jurisprudence of the Rights of the Child, 3 ILSA J. INT'L \& COMP. L. 665 (1997) [hereinafter Pfund]; Elizabeth Kolby, Moral Responsibility to Filipino Amerasians: Potential Immigration and Child Support Alternatives, 2 ASIAN L. J. 61, 77-84 (1995) [hereinafter Kolby]; Gloria F. DeHart, Comity, Conventions, and the Constitution: State and Federal Initiatives in International Support Enforcement, 28 FAM. L. Q. 89 (1994)[hereinafter DeHart]; David F. Cavers, International Enforcement of Family Support, 81 COLUM. L. REV. 994 (1981)[hereinafter Cavers].

5. See Close v. Glenwood Cemetery, 107 U.S. 466, 475 (1883); see infra discussion section II.

6. U.S. CONST., art. VI, cl. 2., "This Constitution, ... shall be the supreme Law of the Land."

7. See 42 U.S.C.A. $\$ \$ 654 \$ 32(A), 659 \mathrm{a}$ (d) (West 1998)(collectively referred to as the International Child Support Enforcement provisions ICSE). 
with the actual language of the statute. Section (II) analyzes the constitutionality of the ICSE provisions' grant of extra-constitutional ${ }^{8}$ powers to the states. It will consider those clauses in the constitution which may give Congress the authority to pass the ICSE provisions. Section (III) analyzes Congress' ability to regulate family law. Finally, this paper proposes two things. First, if the statute is valid, then international child support enforcement should be placed on a completely federal level without local interference by the states into the federal government's foreign policy. Furthermore, if Congress has Commerce Clause authority to regulate here, the provisions can become constitutional without losing the desired effect by removing the language directed toward the states from its content. Second, if Congress is aggrandizing their power to regulate under the commerce clause then the life span of the ICSE provisions is in serious jeopardy.

\section{A STATUTORY ANALYSIS OF THE ICSE PROVISIONS}

At common law, the only legal duty for a father to pay child support not stipulated by contract, was a moral one. ${ }^{9}$ In addition, if a minor child made a contract with a third party, a father could not be held liable unless he explicitly or implicitly consented to the contract. ${ }^{10}$ Current state statutes ${ }^{11}$ and judicial

8. Extra-constitutional powers, as referenced in this paper, means those powers which are not specifically or residually granted to either the state or the federal government by the Constitution, i.e. unconstitutional. The phrase extra-constitutional is amorphous in nature, equally being applied to mean either non-constitutional, not stated in the constitution and thus political in nature, or unconstitutional, actions which are against the expressed provisions in the Constitution. The phrase seemed appropriate in talking about international child support enforcement, another amorphous area of the law.

9. See Shelton v. Springett, 11 C.B. 452, 454-55, 138 Eng. Rep. 549, 550 (1851); Bazeley v. Forder, 3 Q.B. 559, 561 (1868)('There is no obligation on the part of the father to support his children at the common law, the liability is only by force of the statutes as to poor law"). Id.

10. See Shelton, 11 C.B. at 454-455; see also id. at 456 (Maule, J. concurrence). "[T] he mere moral obligation on the father to maintain his child affords no inference of a legal promise to pay his debts." Id.

11. ANN. CAL. CIV. CODE $\$ 4700$ (Supp. 1980); Uniform Civil Liability for Support Act §\$ 2, 3, 9 U.L.A. 174, 177 (1979). Some states have extended the duty of support to stepparents. See, e.g., N.H. STAT. ANN. §§ 546-A:1, 546-A:2 (1974); N.Y.-MCKINNEY's SOC. SERV.L. § 101 (1983 \& Supp. 1986); S.D. COMP. L. \$25-7-8 (1984); UTAH CODE ANN. 1986, \$ 78-45-4.1 (Supp.); WEST's REv. CODE WASH. ANN. $\S 26.16 .205$ (Supp. 1986).; See generally Logan v. Logan, 424 A.2d 403 (N.H. 1980). Note however, in the absence of statutory imposed duty, in common law stepparents have no duty of support for their stepchildren unless the stepparent assumes such a duty. See Chapin v. Superior Court In and For Kern County, 239 Cal. App.2d 851 (1966); Ladd v. Welfare Commissioner, 217 A.2d 490 (1965); Fussell v. Douberly, 206 So.2d 231 (Fla. Dist. Ct. App. 1968); Zeller v. Zeller, 407 P.2d 478 (Kan. 1965); In re Besondy, 20 N.W. 366 (Minn. 1884); Falzo v. Falzo, 202 A.2d 192 (N.J. Super 1964); In re Estate of Turer, 133 N.W.2d 765 (Wis. 1965); In re Fowler, 288 A.2d 463 (Vt. 1972).

Thus, a stepparent can relinquish their duty at any time without an imposition of liability. See Franklin v. Franklin, 253 P.2d 337 (1953); Clevenger v. Clevenger 189 Cal. App.2d 658 (1961); Remkiewicz v. Remkiewicz, 429 A.2d 833 (Conn. 1980); Brown v. Brown, 412 A.2d 396 (Md. 1980); Chestnut v. Chestnut, 
decisions ${ }^{12}$ have placed a duty on both parents to be responsible for the support of their children. ${ }^{13}$

When this duty is breached, children and custodial guardians often look to the courts for relief. Remedies which are available to children for the enforcement of the duty of support include bringing a civil suit against the offending parent, ${ }^{14}$ encouraging the state to bring a criminal suit, ${ }^{15}$ or bringing a suit in equity for the purchase of essential items for the child's maintenance. ${ }^{16}$ Judgment by the court is often times the awarding of specific performance of child support payments. If it is determined that the parent intentionally refused to pay, and payment was economically feasible, penalties for non-compliance include civil contempt, ${ }^{17}$ criminal sanctions, ${ }^{18}$ and if the non-custodial parent is a federal employee, the garnishment of wages. ${ }^{19}$

Child support enforcement has traditionally been the domain of the state government. ${ }^{20}$ However, when the problem of interstate enforcement of child support orders became too pervasive to be ignored, National Conference of Commission on Uniform Laws approved a series of uniform acts, ${ }^{21}$ Revised

147 S.E.2d 269 (S.C. 1966). See generally Mahoney, Support and Custody Aspects of the Stepparent-Child Relationship, 70 CORN. L. REV. 38 (1984).

12. Barnhard v. Barnhard, 252 Ar. 167, 477 S.W.2d 845 (1972); Carter v. Carter, 397 N.Y.S.2d 88 (2nd Dept. 1977); Murredu v. Murredu, 236 S.E.2d 452 (W. Va. 1977).

13. The Equal Protection Clause of the United States Constitution, U.S. CONST. amend XIV, \& 1, also requires both parents to share the responsibility of child support. See generally Orr v. Orr, 440 U.S. 268 (1979) holding that a statute authorizing alimony only to wives and not husbands violated the Equal Protection Clause.

14. McQuade v. McQuade, 358 P.2d 470 (Colo. 1960); Johnson v. Norman 421 N.E.2d 124 (Ohio 1981).

15. State v. Ducey, 266 N.E.2d 233 (Ohio 1970).

16. Greenspan v. Slate, 97 A.2d 390 (N.J. 1953).

17. Yee, What Really Happens in Child Support Cases: An Empirical Study of Establishment and Enforcement of Child Support Orders in the Denver District Court, 57 DEN. L. J. 21,44 (1979).

18. See Day v. State, 481 P.2d 807 (Ok1. Crim. App. 1971) (non-support of child is a continuing criminal offense); see generally THE MODEL PENAL CODE $\$ 207.14$ (Tent. Draft No. 9, 1959) (misdemeanor to fail to support a child, when defendant is capable of payment).

19. 42 U.S.C.A. \$659. The use of garnishment are limited in scope. See Brockelman v. Brockelman, 478 F. Supp. 141 (D.Kan. 1979) (spouse may not garnish amounts owed to the other spouse as income tax refunds). See generally Maj. Alan Cook, The Armed Forces as a Model Employer in Child Support Enforcement: A Proposal to Improve Service of Process on Military Members, $155 \mathrm{ML}$. L. REV. 153, 161 (1998) (arguing that the military seems to be more effective enforcer of child support claims than the local or state govemments).

20. Kolby supra note 4, at 77. See also Gloria F. DeHar, Getting Support Over There, 9 FAM. ADVOC. 34 (1987).

21. See Faye R. Goldberg, Child Support Enforcement; Balancing Increased Federal Involvement with Procedural Due Process, 19 SUFFOLK U. L. REV. 687 (1985) (presenting a history of the federal government involvement in child support issues); see also Kolby supra note 4, at 78. 
Uniform Reciprocal Enforcement of Support Act (URESA) 22 and the Uniform Interstate Family Support Act (UIFSA), ${ }^{23}$ for the states to adopt, and which currently have been enacted in some form in all states. ${ }^{24}$ Under these laws, interstate child support enforcement decrees are treated like any other sisterstate court orders, thus making enforcement possible under the Full Faith and Credit Clause of the Constitution. ${ }^{25}$

22. 9 U.L.A. $381 \S 2(\mathrm{~m})$ (1987). A vast majority of states have repealed the reciprocal enforcement act in favoring instead to adopt the Uniform Interstate Family Support Act (UIFSA), 9. U.L.A. 15 \& 1(19) (Supp. 1993).

23. 9 U.L.A. $15 \& 1$ (19) (Supp. 1993).

24. Uniform Interstate Family Support Act (1996), replacing the Uniform Reciprocal Enforcement of Support Act, has been adopted by forty-nine states and the District of Columbia. ALA. CODE \$§ 30-3a101 to 30-3a-906 (1998); ALASKA STAT. \$\$ 25.25.101 to 25.25.903 (Michie 1998); ARR. REv. STAT. \$\$ 25621 to 25-661; ARK. CODE ANN. $8 \$$ 9-17-101 to 9-17-902 (Michie 1998); CAL. FAM. CODE $\$ \$ 490$ to 4976; Colo. Rev. STAT. ANN. \$\$ 14-5-101 to 14-5-1007; 1997 CONN. ACTs 97-1 (2nd Spec. Sess.); Del. CODE. ANN. tit. 13, \$\$ 601 to 691 (1998); D.C. CODE ANN. \$\$ 30-341.1 to 30-349.1 (1998); FLA. STAT. ANN. \$§ 88.0011 to 88.9051 (West 1998); GA. CODE. ANN. $\$ \S 19-11-100$ to 19-11-191 (Michie 1998); HAW. REV. STAT. §§ 576B-101 to 576B-902 (1998); IDAHO CODE \$\$ 7-1001 to 7-1059 (1998); 750 ILL. COMP. STAT. ANN. 22/100 to 22/999 (West 1998); IND. CODE. ANN. \$\$ 31-18-1-1 to 31-18-9-4 (West 1998); lOWA CODE ANN. §§ 252K.101 to 252K.904 (West 1998); KAN. STAT. ANN. $\$ \$ 23-9,301$ to 23-9,903 (1998); KY. REV. STAT. ANN. \$\$ 407.5101 to 407.5902 (Michie 1998); LA. REV. STAT. ANN. \$\$1301.1 to 1308.2 (West 1998); ME. REv. STAT. ANN. tit. 19-A, $\$ \S 2801$ to 3401; MD. CODE ANN., FAM. LAW $\$ \S 10-301$ to 10-359 (1998); MASS. GEN. LAWS. ANN. ch. 209D, \$\$1-101 to 9-902 (West 1998); MICH. COMP. LAWS. ANN. $\$ \S 552.1101$ to 552.1901 (West 1998); MNN. STAT. ANN. \$\$ 518C.101 to 518C.902 (West 1998); MISS. CODE. ANN. $\$$ 93-25-1 to 93-25-117 (1998); Mo. Ann. Stat. $\$ \$ 454.850$ to 454.997 (West 1998); MONT. CODE. ANN. $\S \S$ 40-5-101 to 40-5-197 (1998); NEB. REV. STAT. \$\$ 42-701 to 42-751 (1998); NEV. REV. STAT. \$\$ 130.0902 to 130.802 (1998); N.H. REV. STAT. ANN. $\$ \$$ 546-B:1 to 546-B:60 (1998); N.M. STAT. ANN. \$\$ 40-6A-101 to 40-6A-903 (Michie 1998); N.Y. FAM. CT. Act. \$\$ 580-101 to 580-905 (1998); N.C. GEN. STAT. \$\$52C-1100 to 52C-9-902 (1998); N.D. CENT. CODE $\$ \$ 14-12.2-01$ to 14-12.2-49 (1998); OHIO REV. CODE. ANN. $\S \S 3115.01$ to 3115.59 (West 1998); OKLA. STAT. ANN. tit. 43, §§ 601-100 to 601-901 (1998); OR. REV. STAT. $\$ 110.300$ to 110.441 (1998); 23 PA. CONS. STAT. ANN. $\S 7101$ to 7901 (West 1998); R.I. GEN. LAWS §§ 15-23-1 to 15-23-53 (1998); S.C. CODE ANN. \$\$ 20-7-960 to 20-7-1166 (Law. Co-op. 1998); S.D. CODIFIED LAWS $\S \S 25-9 B-101$ to 25-9B-902 (Michie 1998); TENN. CODE. ANN. \$§ 36-5-2001 to 36-5-2902 (1998); TEX. FAM. CODE ANN. $\$ \S 159.001$ to 159.902; (West 1998); UTAH CODE ANN. $\$ \S 78-45 f-200$ to 78 45f-901 (1998); VT. STAT. ANN. tit. 1SB, \$\$ 101 to 904 (1998); VA. CODE ANN. \$\$ 20-88.32 to 20-88.82 (Michie 1998); WASH. REV.CODEANN. \$\$ 26.21.005 to 26.21.916 (West 1998); W.VA.CODE \$ $\$$ 48B-1-101 to 48B-9-903 (1998); WIS. STAT. ANN. \$\$ 769.101 to 769.903 (West 1998); WYO. STAT. ANN. \$§ 20-4-139 to 20-4-189 (Michie 1998).

A few states have enacted the UIFSA, but have not repealed their Uniform Reciprocal Enforcement of Support Act statutes: Georgia: GA. CODE ANN. \$§ 19-11-40 to 19-11-81 (1998); Iowa: IOWA CODE ANN. $\S \S 252 A .1$ to 252A.25 (West 1998); and Michigan: MICH. COMP. LAWS ANN. $\$ \$ 780.151$ to 780.183 (West 1998). Kentucky's adoption statute of the UIFSA, and repeal of the RURESA, would be deemed effective when the United States Congress requires the UIFSA be adopted by the several states. See KY. REV. STAT. ANN. $\$ 407.5101$ to 407.5902 (Michie 1998).

New Jersey is the only state which has not adopted the Uniform Family Support Act, but kept their URESA statute. N.J. STAT. ANN. \$\$ 2A:4-30.24 to 2A:4-30.64 (West 1998).

25. U.S. CoNST. art. IV, § 1: "Full Faith and Credit shall be given in each State to the public Acts, Records and judicial Proceedings of every other State." All United States' states must give the same effect 
A problem arises when discussing the enforcement of foreign child support decrees. Unlike in the interstate model of child support enforcement, full faith and credit does not apply to foreign judgments, ${ }^{26}$ states are not allowed to make treaties with foreign nations, ${ }^{27}$ and enforcement of foreign court orders is by the discretion of the state court ${ }^{28}$ or through a reciprocal arrangement between the

to a judgment of a court of a sister-state as if the judgment was rendered in the requesting state's court, as long as the judgment was final and the court who entered the order had valid jurisdiction over the case.

26. See U.S. CONST. art. IV. \& 1. The Full Faith and Credit Clause does not imply that the state court must recognize decisions from foreign nations just sister-states of the United States.

In Nardi v. Segal, 234 N.E.2d 805 (Ill. 1968), an ex-wife brought a suit for arrearages of child support against her ex-husband. Id. at 806 . The child support enforcement decree was based on an Israeli divorce decree. Id. At the time the complaint was filed, the wife was living in Israel, the ex-husband in Chicago, and the ex-husband had not paid nine months of child support. ld. The court stated that the doctrine of comity did not require it to enforce a decree from a foreign country, nor did the Full-Faith and Credit Clause of the United States Constitution require the court to recognize or enforce a decree from a foreign country. But see Wolff v. Wolff, 389 A.2d 413, (Md. Ct. Spec. App. 1978), where the Maryland Court of Special Appeals held that the Uniform Foreign Money-Judgments Recognition Act did not preclude the state court from recognizing or enforcing an alimony decree obtained in England. Thus recognition of the foreign order by the state court is not based on whether the court had jurisdiction but on the doctrine of comity.

Recognition of a foreign judgment does not imply enforcement of the judgment. The Uniform Foreign-Money Judgment Recognition Act (UFMJRA) excludes judgments for "support in matrimonial or family matters" from its definition of "foreign judgments." Uniform Foreign-Money Judgment Recognition Act §1(2); See also 100 A.L.R.3d 792 (explaining the construction and application of the Uniform ForeignMoney Judgment Recognition Act).

By legislative promulgation, twenty-eight states, Washington, DC and the Virgin Islands have adopted the UFMJRA. See ALASKa STAT. $\$ \$ 09.30 .100$ to 09.30.180 (Michie 1998); CAL. Crv. ProC. CODE $\$ 1713$ to 1713.8 (West 1998); CoLo. Rev.STAT. ANN. $\$ 13-16-101$ to 13-62-109 (West 1998); ConN. GEN. STAT. ANN. $\$ \$ 50 a-30$ to 50a-38 (West 1998); DEL. CODE ANN. tit. 10, $\$ 4801$ to 4808 (1998); D.C. CODE ANN. $\S \S 15-381$ to 15-388 (West 1998); FLA. STAT. ANN. \$§ 55.601 to 55.607 (West 1998); GA. CODE ANN. $\S$ 9-12-110 to 9-12-117 (1998); HAW. Rev. STAT. §§ 658C-1 to 685C-9 (1998); IDAHO CODE §§ 10-1401 to 10-1409 (1998); 735 ILL. COMP. STAT. ANN. 5/12-618 to 5/12-626 (West 1998); IOWA CODE ANN. §§ 626B.1 to 626B.8 (West 1998); MD. CODE ANN., CTS. \& JUD. PROC $\$ \$ 10-701$ to 10-709 (1998); MASS. GEN. LAWS ANN. ch. 235, § 23A (West 1998); MICH. COMP. LAWS ANN. \$§ 691.1151 to 691.1159 (West 1998); MINN. STAT. ANN. \$ 548.35 (West 1998); Mo. ANN. STAT. $\$ \$ 511.770$ to 511.787 (West 1998); MONT. CODE. ANN. $\S \S 25-9-601$ to 25-9-609 (1998); N.J. STAT. ANN. §§ 2A:49A-16 to 2A:49A-24 (West 1998); N.M. STAT. ANN. 8 39-4B-1 to 39-4B-9 (Michie 1998); N.Y.C.P.L.R. 5301 to 5309 (McKinney 1998); N.C. GEN. STAT. $\S \S 1 C-1800$ to 1C-1808 (1998); OHIO REV. CODE ANN. $\$ \S 2329.90$ to 2394.94 (Anderson 1998); OKLA. STAT. ANN. tit 12, $\$ \$ 710$ to 718 (West 1998); OR. REv. STAT. $\$ \$ 24.200$ to 24.255 (1998); 42 PA. CoNS. STAT. $\$ 22001$ to 22009 (1998); TEX. CTV. PRAC. \& REM. CODE ANN. $\S \S 36.001$ to $36.008,36.0041$ to 36.0044 (West 1998); VA. CODE ANN. $\$ \$ 8.01-465.6$ to 8.01-465.13 (Michie 1998); WASH. REV. CODE. ANN. $\$$ 6.40.010 to 6.40.915 (West 1998); V.I. CODE ANN. tit. $5, \S \S 561$ to 569 (1998).

By adopting the UFMJRA, state courts are precluded from recognizing and enforcing child support decrees from foreign countries. See generally Nardi, 234 N.E.2d at 805; Zalduendo v. Zalduendo, 360 N.E.2d 386 (IIl. 1977).

27. U.S. CONST. art. I, \& 10.

28. See Hilton v. Guyot, 159 U.S. 113 (1895) (stating that it is the state's courts discretion whether to recognize a foreign nation's court judgment since under the principle of comity of nations the state court was under no obligation). 
states and the foreign government. ${ }^{29}$ It is the validity of the last category where the main thrust of this paper will be focused.

\section{A. The Statutory Language of the ICSE Provisions}

Legislation is presumed constitutional, unless sufficient evidence is presented to rebut the presumption. ${ }^{30}$ The Supreme Court has held that when a statute contains patent inconsistencies against the expressed provisions of the federal constitution, it is facially invalid. ${ }^{31}$ There is case law in which a facially neutral statute, when applied, posed latent inconsistencies with federal law. ${ }^{32}$ Such statutes are also invalid. ${ }^{33}$ If a statute contains possible inconsistencies, the legislature should ensure that the language of the statute clearly reflects a valid legislative intent. ${ }^{34}$ If the statute is invalid when applied, the legislature should repeal such an ineffective statute.

The International Child Support Enforcement (ICSE) ${ }^{35}$ provisions are comprised of two statutory acts. The first one, under 42 U.S.C.A. $\$ 659 \mathrm{a}$, is entitled International Support Enforcement. ${ }^{36}$ The second provision, also

29. Pfund, at 674-75; Kolby, at 78; Cavers, at 1037 (stating that in absence of federal exercising any power in enforcing international child support decrees, the states have in increasing number entered into reciprocity arrangement with foreign nations).

Any future reference to foreign governments or foreign states means government of nation states and not the government of the states of the United States.

30. See Close v. Glenwood Cemetery, 107 U.S. 466, 475 (1883); Sloan v. Baker, 10 P.2d 362, 364 (Or. 1932). This presumption is asserted to prevent the courts from rewriting the Constitution to adapt the document to present life. Instead, the presumption gives force to newly enacted laws, at the same time not disrupting the actual language of the Constitution. Rhode Island v. Palmer, 253 U.S. 350, 410 (1920)(J. Clarke, dissenting).

But see Oliver W. Holmes, The Path of Law, 10 HARV. L. REV. 457, 469 "It is revolting to have no better reason for a rule of law than that it was laid down in the time of Henry IV. It is still more revolting if the ground upon which it was laid down have vanished long since, and the rule simply persists from blind imitation of the past." Id.

31. Gibbons v. Ogden, 22 U.S. 1 (1824); McCulloch v. Maryland, 17 U.S. 316 (1819). The Supremacy Clause dictates that no other law shall be above the federal Constitution. "This Constitution... shall be the supreme Law of the Land." U.S. CONST. ant. VI, cl. 2. State laws and state constitutions can give a broader interpretation of a constitutional right, but not a narrower one.

32. See E.E.O.C. v. Illinois, 69 F.3d 167, 170-171 (1995).

33. See id.

34. In United States v. Lopez, 115 S.Ct. 1624 (1995), prior to the Supreme Court deciding the matter, Congress had adopted an amendment to the statute at issue in order, so that it may reflect a legislative history which included an explanation on the connection between the impact of the regulation of gun possession on school grounds and interstate commerce.

35. See 42 U.S.C.A. $\$ \$ 654$ q32(A), 659a (d) (West 1998).

36. "(a) Authority for declarations

(1) Declarations

The Secretary of State, with the concurrence of the Secretary of Health and Human

Services, is authorized to declare any foreign country (or a political subdivision 
incorporated under the federal Social Security Act, regulates state plans for child and spousal support, under 42 U.S.C.A. $\$ 654 .^{37}$

The current practice among state governments has been to enter into agreements with foreign nations to address the issue of international child support enforcement. ${ }^{38}$ The ICSE provisions ${ }^{39}$ of the federal Social Security Act makes reference to the current arrangement between states and foreign nations, ${ }^{40}$ while simultaneously granting authority to the State Department and

thereof) to be a foreign reciprocating country if the foreign country has established, or undertakes to establish, procedures for the establishment and enforcement of duties of support owed to obligees who are residents of the United States, and such procedures are substantially in conformity with the standards prescribed under section (b) of this section.

(3) Form of declaration

A declaration under paragraph (1) may be made in the form of an international agreement, in connection with an international agreement or corresponding foreign declaration, or on a unilateral basis.

(b) Standards for foreign support enforcement procedures

(2) Additional elements

The Secretary of Health and Human Services and the Secretary of State, in consultation with the States, may establish such additional standards as may be considered necessary to further the process of this section.

(d) Effects on other states

States may enter into reciprocal arrangements for the establishment and enforcement of support obligations with foreign countries that are not the subject of a declaration pursuant to subsection (a) of this section, to the extent consistent with Federal law."

37. "A State plan for child and spousal support must-

\$ 32 (A) provide that any request for services under this part by a foreign reciprocating country or a foreign country with which the States has an arrangement described in section [42 U.S.C.S. $\$ 659$ a(d)] shall be treated as a request by a state;

(B) provide, at State option, notwithstanding ... any other provision of this [act], for services under the plan for enforcement of a spousal support order not described in paragraph (4)(B) entered by such a country (or subdivision); and

(C) provide that no application will be required from, and no costs will assessed for such services against, the foreign reciprocating country or foreign obligee (but costs may at State option be assessed against the obligor)."

38. See supra note 3.

39. See 42 U.S.C.A. $\$ \S 654$ q32(A), 659a (d) (West 1998).

40. See id. The language in subsection (d), entitled "Effect on other laws" gives the states the authority to enter into reciprocal enforcement agreements with foreign nations as long as the country is not one already declared by the State Department to be a reciprocating nation under subsection (a) or inconsistent with federal law. Id. at (d).

The current practice of international child support enforcement has been through Parallel Unilateral Policy Declarations (PUPDs). Under the PUPDs, and the principle of comity, the state, through its courts would agree to recognize foreign child support decrees if the foreign nation would reciprocate and afford the 
the Department of Health and Human Services to designate foreign nations as reciprocating countries who will honor the United States child support decree. ${ }^{41}$ It also creates an imposition upon the state courts to recognize and treat foreign judgments for child support as if it originated from a sister-state. ${ }^{42}$ In enacting the ICSE provisions, Congress sought to federalize the issue of international child support enforcement ${ }^{43}$ by encouraging the federal government to take a more active role in enforcement. ${ }^{44}$ The ICSE provisions, in various incarnations, were debated and dissected in Congress for over two years before being signed into law..$^{45}$

state citizens the same opportunity for enforcement of United States child support decrees. Some have argued that with the passage of the ICSE provisions the federal government will be more inclined to begin negotiations with foreign countries, both past participants in the PUPDs and other nations, regarding child support enforcement. See DeHart, at 89.

41. See 42 U.S.C.A. \$ 659a (a) (West 1998).

42. See 42 U.S.C.A. at \$ 654 . Section 654 entitled, "State plan for child and spousal support" requires that any state plan for child support enforcement must treat intemational child support claims as if there are interstate child support claims. See id at 1 32(A).

Child support enforcement has traditionally been the domain of the state government. See Kolby, at 77. See also Gloria F. DeHart, Getting Support Over There, 9 FAM. ADVOC. 34 (1987). However, when the problem of interstate enforcement of child support orders became too pervasive to be ignored, the National Conference of Commission on Uniform Laws passed a series of uniform acts, Revised Uniform Reciprocal Enforcement of Support Act (URESA), 9 U.L.A. $381 \S 2(\mathrm{~m})(1998)$, and the Uniform Interstate Family Support Act (UIFSA), 9 U.L.A. 15 \$ 1(19) (1998), for the states to adopt, and which currently have been enacted in some form in 49 states and the District of Columbia. See discussion following note 24.

Under state laws interstate child support enforcement decrees are treated like any other sister-state court decrees, thus enforcement is possible under the principles of Full Faith and Credit Clause of the Constitution. See U.S. CONST. art. IV, § 1: "Full Faith and Credit shall be given in each State to the public Acts, Records and judicial Proceedings of every other State." All United States' state courts must give the same effect to a judgment of a court of a sister-state as if the judgment was rendered in the requesting state's court, as long as the judgment was final and the court that entered the order had valid jurisdiction over the case.

Under the principles of full faith and credit, and comity of nations, state courts are allowed to recognize foreign court judgments at their discretion. See Hilton v. Guyot, 159 U.S. 113 (1895). However, recognition does not imply that the judgment is considered conclusive evidence of an obligation to pay, just prima facie evidence that a debt exists. Id.

43. See P.L. 104-193 § 39. "The U.S. and selected foreign nations maybe able to help each other deal with the problem of parents and former spouses crossing boundaries to avoid support payments." Id.

The United States is not a signatory to any of the United Nations treaties pertaining to international child support enforcement. Convention on the Recovery Abroad of Maintenance Obligations, June 20, 1956, 268 U.N.T.S. 3; Convention on the Recognition and Enforcement of Decisions Relating to Maintenance Obligations, Oct. 2, 1973, 1021 U.N.T.S. 209; see also 136 Cong. Rec. E2904 (daily ed. Sept. 19, 1990)(statement of Rep. Kennelly).

Prior to the passage of the ICSE provisions, no law existed on the issue of international child support enforcement. 141 Cong. Rec. H12317, H15427 (daily ed. December 21, 1995); P.L. 104-193 \& 39.

44. See P.L. 104-193 \$39 International Child Support Enforcement. The provisions were to "allow and encourage the Secretary of State to pursue reciprocal support agreements with other nations." Id.

45. Representative Kennelly introduced legislation of January 4, 1995, designed to improve 
Congress expressed four specific reasons for passing the ICSE provisions: (1) to provide a remedy to U.S. parents in the enforcement of child support abroad, ${ }^{46}(2)$ to address the fact that states do not have the power to enter into treaties, (3) to encourage the Department of State to take a more active role in pursuing agreements with foreign nations on this issue, and (4) to place on a federal level the issue of international child support enforcement in order to cultivate solutions to the problem via foreign policy. ${ }^{47}$

Whether the statute provides an adequate remedy to U.S. parents trying to enforce child support claims abroad remains a pressing issue since its enactment. ${ }^{48}$ The statute fails to provide any expressed jurisdictional predicate, stating which forum or choice of law the parents will utilize. ${ }^{49}$ The statute does declare that a request by a reciprocating foreign nation should be treated as if it were a request by a sister state. ${ }^{50}$ Yet, unlike international requests, interstate requests have the protection of both state and federal law.

Each state has adopted into their laws provisions allowing for recognition of outside state claims, thus ensuring interstate requests receive the same treatment as intrastate requests for assistance. Additionally, the Full Faith and Credit Clause of the Constitution precludes the courts of one state from discriminating against and not recognizing judgments from another state. Comparatively, international child support embodies two distinct principles of

interstate enforcement by urging Congress to ratify the U.N. treaties on international child support enforcement and thus treat international support claims as if they were interstate support claims. See H.R. 95, 104th Cong. $\$ 424$ (1995). Senator Bradley introduced similar legislation on February 16, 1995. See S. 456, 104th Cong. \$172 (1995); see also S. 442, 104th Cong. $\$ 172$ (1995)

Also on January 4,1995, the clauses pertaining to state authority to enter into agreements with other nations were introduced as part of the proposed Balance Budget Act, HR 2491, 104th Cong. \$12370 (1995), and the proposed Personal Responsibility and Work Opportunity Act of 1995, HR 4, 104th Cong. \$371 (1995). It was not until October 23, 1995, did the Senate propose similar legislation, but only pertaining to the power of the State Department to designate foreign nations. S. 1357, 104th Cong. $\$ 7371$ (1995). The legislation was re-introduced by Senator Daniel P. Moynihan, in its entirety on June 5, 1996. See S. 1841 , 104th Cong. $\$ 271$ (1996).

46. Currently, the United States is not a signatory to any major treaty or international convention regarding international child support. The current reciprocal agreements by the states with foreign countries were done pursuant to the model established in the URESA.

47. H.R. Rep. No. 104-430, at 44 (1995); H.R. Rep. No. 104-350, at 44 (1995); P.L. 104-193, Title III, §39; 141 Cong. Rec. H15317-01, H15427 (1995); 141 H12509-01 (Pt. 2), H12976 (1995).

48. See Pfund at 665,675 (citing the ICSE provision, 42 U.S.C. $\$ 659$ a, as a new remedy for the problem of international enforcement.); Dehart, at 93-4 (explaining the system between the state and foreign governments in enforcing international orders under the URESA system); See also Cavers, at 997-1000 (addressing the issue of enforcing claims in the United States and abroad prior to the passage of the ICSE provisions).

49. See Carol S. Bruch, Statutory Reform of Constitutional Doctrine: Fitting International Shoe to Family Law, 28 U.C. DAVIS L. REV. 1047, 1049 (1995).

50. 42 U.S.C. $\$ 654$ \32 (A). 
law: family law and international affairs. Family law has traditionally been the domain of state government and state courts. ${ }^{51}$ Early on, the Supreme Court found federal courts lack the necessary judicial expertise in domestic issues and state courts were the best forum to handle such delicate matters. ${ }^{52}$ Additionally, recognition of foreign court judgments are not automatic, but instead are based solely on the discretion of the court to recognize the claim of an international court judgment. ${ }^{53}$ Unlike Full Faith and Credit recognition, the recognition by the court is not conclusive evidence that child support is due, but merely evidence that a debt is owed to the complaining party. ${ }^{54}$ Therefore, international claims can not be treated similar to interstate claims because of the broad judicial discretion by the state courts to accept or deny recognition of a foreign judgments. ${ }^{55}$

The language of the statute is not directed towards state courts, but to state governments. The statute expresses that "states may enter into reciprocal arrangements for the establishment and enforcement of support obligations with foreign countries." 56 Identifying the constitutional basis for how a federal statute may effect interstate commerce may aid in interpreting the legislative intent if the law is on questionable grounds. ${ }^{57}$ A state court can hear a case arising under federal law unless Congress says otherwise. ${ }^{58}$ State courts have inherent authority and are presumably competent to adjudicate claims arising under the laws of the United States. ${ }^{59}$ This presumption of concurrent jurisdiction can be rebutted by explicit statutory language or unmistakable implication from legislative history or clear incompatibility between state court jurisdiction and federal interest. ${ }^{60}$ Federal question jurisdiction in district courts dictates that federal courts have original jurisdiction of all civil actions

51. Barber v. Barber, 62 U.S. 582, 590-92 (1858)(holding that matters dealing with domestic relations are to be handled by the state courts, not the federal courts, since there exist no history of family law on the federal level).

52. Id.

53. supra the discussion following note 46.

54. Id.

55. Although URESA was enacted to facilitate interstate child support enforcement, only about $41 \%$ of state courts actually enforce claims from other states. 138 Cong. Rec. H7326 (statement by Rep. Hyde).

56. 42 U.S.C.A. §659a (d) (West 1998).

57. Id.

58. Howlett v. Rose, 496 U.S. 356, 380-81 (1990).

59. Tafflin v. Levitt, 493 U.S. $455,458-9$ (1990).

60. Id. See also U.S. CoNST. art. I, §10; id. at art. II, §2; id. at amend. X. See generally Printz v. U.S., 117 S. Ct. 2365 (1997); U.S. Term Limits v. Thornton, 514 U.S. 779 (1995); U.S. v. Lopez, 514 U.S. 549 (1995)(Kennedy's concurrence); N.Y. v. U.S., 505 U.S. 144 (1992)(holding that Congress' efforts to mandate state toxic waste clean up violated the Tenth Amendment); Missouri v. Holland, $40 \mathrm{~S}$. Ct. 382 (1920); Condon v. Reno, 155 F. 3d 453 (1998). 
arising under the Constitution, ${ }^{61}$ federal laws or treaties of the United States. ${ }^{62}$ The ICSE provisions are silent as to the jurisdictional predicate to be employed in bringing claims under this statute. Therefore, the statute does not explicitly rebut the presumption of concurrent jurisdiction.

\section{B. Legislative History of the ICSE Provisions}

The legislative history of the ICSE provision gives jurisdiction by implication to the federal court over the issue of international child support enforcement. ${ }^{63}$ By claiming to provide a remedy to United States parents in the enforcement of child support abroad, the language in the ICSE provisions is designed to allow the states to continue making arrangements with foreign nations. ${ }^{64}$ If the statute had vested jurisdiction in both state and federal courts, the legislative history would not have mentioned that states can not enter into treaties with foreign nations. ${ }^{65}$ In addition, allowing states to enter into these agreements does not provide a direct remedy to parents who want to enforce international claims for child support. Even if such agreements are legal, by not providing a jurisdictional predicate within the statute itself, parents are not afforded adequate remedies to enforce child support claims abroad.

The congressional record and debates indicate that the legislature envisioned a more efficient enforcement of international child support claims. ${ }^{66}$ The legislative history of ICSE provisions acknowledges that states can not make treaties. ${ }^{67}$ In addition, one purpose of the statute was to authorize and motivate the federal government to take action in the area of child support since the United States has not signed any treaties regarding this issue. ${ }^{68}$ Further-

61. See 28 U.S.C. $\$ 1331$ (1998). Original jurisdiction in this context means non-appellate jurisdiction. See also 28 U.S.C. $\$ 1251$ (b) (1998) (stating that "[t]he Supreme Court shall have original but not exlusive jurisdiction of: (1) All actions or proceedings to which ambassadors, other public ministers, consuls, or vice consuls of foreign states are parties; ... (3) All actions or proceedings by a State against the citizens of another States or against aliens").

62. 28 U.S.C. $\$ 1331$ (1998).

63. See Pfund, at 674-675; See also DeHart, at 110 (calling for Federal government involvement in international child support cases).

64. 42 U.S.C.A. $\$ 659$ a (d) (West 1998).

65. See infra the discussion regarding the prohibition on states forming treaties with foreign nations.

66. See 136 Cong. Rec. E2904-01 (1990)(Rep. Kennelly calling for a ratification by the United States of the international treaties dealing with child support enforcement); See also 141 Cong. Rec. H358107, H3662 (1995) (proposing the adoption of the United Nations Convention of 1956, the so called "New York" Convention, pertaining to international child support enforcement).

67. H.R. Rep. No. 104-430, at 44 (1995); H.R. Rep. No. 104-350, at 44 (1995); P.L. 104-193, Title III. §39; 141 Cong. Rec. H15317-01, H15427 (1995); 141 H12509-01 (Pt. 2), H12976 (1995).

68. P.L. 104-193, Title III, $\$ 39$. 
more, the legislative history articulates that international child support enforcement claims should be treated like inter-state claims. ${ }^{69}$

\section{Statutory Analysis of the ICSE Provisions}

Nothing in the statutory language or history intimates that the legislature contemplated a non-custodial parent ever bringing a claim against the execution of the order, under the provisions, as being unconstitutional or outside the scope of the state's authority. ${ }^{70}$ The specific language of the ICSE provisions, create three functions. First, the provisions can be interpreted as an enabling statute, giving the federal government the right to act on the states behalf. ${ }^{71}$ Second, it is a supplementary statute, giving the states the right to make arrangements with foreign nations in the absence of the federal government action. ${ }^{72}$ Finally, the provisions act as a regulatory statute, requiring the states to give similar treatment to international child support claims as they would to inter-state claims. ${ }^{73}$ Allowing states to contract with foreign nations contradicts the grant of jurisdiction to federal, rather than state courts.

The legislative history does not explicitly illustrate whether it was the intention of the legislature to give both the federal and state governments concurrent jurisdiction in the field of international child support enforcement. ${ }^{74}$

69. See supra the discussion following notes 44-48.

70. P.L. 104-193, Title III §39; H.R. 3857, 104th Cong. \$§ 41712, 42424 (1996); H.R. 3832, 104th Cong. $\$ 3832$ (1996); S. 1867, 104th Cong. $\$ 371$ (1996); H.R. 3612, 104th Cong. $\$ 271$ (1996); S. 1841, 104th Cong. \$ 271 (1996); H.R. 3453, 104th Cong. $\$ 171$ (1996); H.R. 3266, 104th Cong. $\$ 371$ (1996); H.R. 2915, 104th Cong. §971 (1996); H.R. Rep. No. 104-725 at 41 (1996); H.R. 2491, 104th Cong. § 12370 (1995); H.R. 2491, 104th Cong. $\$ 7371$ (1995); H.R. 2530, 104th Cong. \$ 9472 (1995); S. 1357, 104th Cong. $\S 7371$ (1995); H.R. 4, 104th Cong. \$ 971 (1995); S. 1117, 104th Cong. \$ 572 (1995); S. 840, 104th Cong. $\S 472$ (1995); H.R. 1267, 104th Cong. \& 472 (1995); H.R. 1250, 104th Cong. \$ 372 (1995); S. 442, 104th Cong. $\$ 172$ (1995); S. 456, 104th Cong. $\$ 172$ (1995); H.R. 785, 104th Cong. \$172 (1995); H.R. 95, 104th Cong. \$ 424 (1995); H.R. 2491, 104th Cong. $\$ 12370$ (1995); H.R. 4, 10th Cong. $\$ 371$ (1995); H.R. Rep. No. 104-430 at 371 (1995); H.R. Rep. No. 104-430 at 44 (1995); H.R. Rep. No. 104-350 at 12370 (1995); H.R. Rep. No. 104-350 at 44 (1995); 142 Cong. Rec. H8829-02, H8925 (1996); 142 Cong. Rec. H7907-04, H7947 (1996); 142 Cong. Rec. S8226-01, S8226(1996); 142 Cong. Rec. H15317-01, H15351 (1995); 141 Cong. Rec. H15317-01, H15427 (1995); 141 Cong. Rec. H13379-01, H13589 (1995); 141 Cong. Rec. H12509-01 (Pt. 1), H12720 (1995); 141 Cong. Rec. S16159-01, S16284 (1995); 141 Cong. Rec. S15852-01, S15945 (1995); 141 Cong. Rec. H10995-01, H11312 (1995); 141 Cong. Rec. S12428-02, S12501 (1995); 141 Cong. Rec. S12968-01, S13020 (1995); 141 Cong. Rec. S11894-01, S11922 (1995); 141 Cong. Rec. S1 1640-01, S11707 (1995); 141 Cong. Rec. H3742-04, H3759 (1995); 141 Cong. Rec. H3581-07, H3662 (1995); 141 Cong. Rec. S2823-02, S2886 (1995); 140 Cong. Rec. S14479-02, S14522 (1994).

71. See 42 U.S.C.A. §659a(a) (West 1998).

72. Id. at $\$ 659 \mathrm{a}(\mathrm{d})$.

73. Id. §654(32); see also H.R. Rep. No. 104-430, at 44 (1995); H.R. Rep. No. 104-350, at 44 (1995); P.L. 104-193, Title III, §39; 141 Cong. Rec. H15317-01, H15427 (1995); 141 H12509-01 (Pt. 2), H12976 (1995).

74. See supra discussion following notes 44-48. 
Yet, the statutory history, by implication, gives federal question jurisdiction over international child support enforcement to the federal courts. ${ }^{75}$ Although child support is best settled in state courts, the international nature of the statute indicates that Congress envisioned the federal government and its courts controlling the issue.

\section{CONSTITUTIONAL ANALYSIS OF THE ICSE PROVISIONS}

The structure of the Constitution creates a dual sovereignty, where by the federal and state governments are both vested with and limited by certain powers. $^{76}$ The federal government is one of enumerated powers whose authority is defined by the Constitution. ${ }^{77}$ All residual power, not expressly denied by the Constitution, is vested in the state government and the people. ${ }^{78}$ Analyzing the federal government's authority possesses within the Constitution has been twofold, formalistic and functionalistic. A formalistic view of the United States Constitution asserts that if the constitution does not expressly grant the federal government the authority to act, it implicitly forbids. ${ }^{79} \mathrm{~A}$ functionalistic view of the Constitution states that what the Constitution does not expressly prohibit or limit, it implicitly permits. ${ }^{80}$ There are many articles which suggest that international child support enforcement should be viewed under a functionalistic test. ${ }^{81}$ Although the court seems to apply both approaches, ${ }^{82}$ more recent Supreme Court decisions have indicated a trend towards utilizing a formalistic analysis to federalism questions ${ }^{83}$ Following the modern trend of the court, the paper analyzes Congress' authority to enact the ICSE provisions under a formalistic microscope.

Under the Constitution, full authority over foreign affairs is given to the federal government. ${ }^{84}$ The Constitution expressly prohibits those activities by

75. Id.

76. U.S. CONST. et. seq.

77. Id. at art. I, et. seq.

78. Id. at amend. $\mathrm{X}$.

79. Harold H. Koh, Is International Law Really State Law?, 111 HARV. L. REV. 1824, 1846-1848 (1998)[hereinafter Koh].

80. Id.

81. See DeHart, at 108-109; Pfund, at 765.

82. Cf. South Carolina v. Baker, 485 U.S. 505 (1987); Garcia v. San Antonio Metropolitan Transit Authority, 471 U.S. 1049 (1984) with Printz .v United States, 117 S. Ct. 2365 (1997); New York v. United States, 112 S. Ct. 2408 (1992). See also Condon v. Reno, 155 F.3d 453, 461-63 (4th Cir. 1998)(following the Printz decision, stating that the federal government can not single out states to implement federal policy).

83. Id.

84. Holmes v. Jennison, 39 U.S. 649, 665-66 (1840); See also Bilder, at $821-3$ (presenting the current trend of state and local governments entering in the arena of foreign policy from "sister-city" programs to direct economic agreements to declarations of being nuclear-free zones). Bilder laments that despite the apparent intrusion of states and local governments into foreign policy making ventures, neither 
state and local governments which invade the realm of expressed powers given to the federal government, ${ }^{85}$ including negotiating with foreign nations on matters of foreign affairs. ${ }^{86}$ Congress may have the power to authorize state and local governments to participate in activities which would ordinarily invade in the realm of the federal government's control of foreign affairs, ${ }^{87}$ however a grant of such power is inconsistent with the Constitution's delegation of exclusive power of foreign policy to the President and Congress. ${ }^{88}$ Thus the express language of the Constitution answers the question of what limits the constitution places on the state government ${ }^{89}$ and who has the ultimate power in matters of foreign affairs. ${ }^{90}$ Therefore, "any judgments as to what constitutes appropriate state or local involvement in foreign affairs ought to be made primarily by the political branches, in which the federal foreign relations power is lodged." 91

\section{A. Treaty Making and State Treaty Prohibiting Clauses}

Every word within the Constitution is significant and has meaning. ${ }^{92}$ The Supreme Court has defined a treaty as "an instrument written and executed with the formalities customary among nations." 93 Under the Constitution, the President, with the advice and consent of the Senate, holds the exclusive power to make treaties. ${ }^{94}$ The Constitution neither grants a similar concurrent power in the legislative, ${ }^{95}$ nor in the judicial branch of the federal government. ${ }^{96}$ In addition, the Constitution explicitly prohibits the state governments from

Congress nor the Executive branch has hastened to react to the current situation. Id. See generally United States v. Pink, 315 U.S. 203, 233 (1942); Hines v. Davidowitz, 312 U.S. 52, 63 (1941); United States v. Belmont, 301 U.S. 324, 331 (1937); United States v. Curtiss-Wright Export Corp., 299 U.S. 304, 318 (1936).

85. Cf. U.S. CONST. art. I, \$10. at art. II. § 2.

86. Curtiss-Wright Export Corp., 299 U.S. 304, 316 (1936).

87. Bilder, at 826.

88. U.S. CONST. art. II, §2, cl. 2; id. at Art. l, §8, cl. 2. See also Bilder, at 827-8.

89. U.S. CoNST. art. I, \&10. et seq. (cl. 1 : bars the state governments from making treaties with foreign nations, clause three bars states, without Congressional consent, from entering into compacts with foreign nations).

90. U.S. CONST. art. II, $\$ 2$ et seq., id. at Art. I, §8, cl. 2.; See also Bilder, at 829.

91. Bilder, at 830 . This statement can be interpreted one of two ways. If states have any foreign affairs power, such power must be granted by the political branches of the federal government. However, if it can be legitimately argued, as presented infra through out this paper, that there exist an absolute exclusion of state and local government in foreign affairs, a grant to the states of such power creates an interference by the states into the federal government's ability to negotiate in foreign affairs.

92. Gibbons v. Ogden, 9 Wheat 1 (1824); Jennison, 39 U.S. at 570-71.

93. Jennison, 39 U.S. at 571.

94. U.S. CONST. art. II, \$2, cl. 2.

95. Id. at art. I et seq.

96. Id. at art. III et seq. 
entering into agreements with foreign nations. ${ }^{97}$ Congress has no authority, under the Constitution, to grant states treating making power. ${ }^{98}$ Furthermore, there exist no implied authority by the federal government to allow states to enter into agreements with foreign nations. ${ }^{99}$ Interpreting the text of Constitution, courts have held that the President, along with the executive branch, hold exclusive power to make treaties and to conduct the foreign affairs of the United States. ${ }^{100}$ Accordingly, the court's definition of a treaty, implies that only sovereign nations, not sovereign states of nations, can enter into such agreements.

The structure of the Constitution supports the contention that states do not possess any powers within the realm of foreign affairs. ${ }^{101}$ Although the Constitution creates a dual sovereignty, ${ }^{102}$ the states have ceded their power to the federal government in interstate ${ }^{103}$ and international matters, ${ }^{104}$ so that the country is able to act with a unified voice. ${ }^{105}$ Thus all powers to act in the area of foreign relations is vested in the federal government. ${ }^{106}$

Despite the explicit Constitutional language and the structure of the Constitution, prohibiting treaties between states and foreign nations, early Supreme Court cases addressed the issue of whether certain state actions triggered the constitutional prohibitions. ${ }^{107}$ In Holmes v. Jennison, ${ }^{108}$ the Court addressed the issue whether the Governor of Vermont could assist Canada by detaining and extraditing Holmes, a Canadian resident, who had committed a

97. Id. at art. I, $\$ 10$, cl. 1 .

98. U.S. CoNST. art 1, $\$ 10$, cl. 1. See also Rhode Island v. Massachusetts, 37 U.S. 657, 725, 735 (1838).

99. Sloan v. Baker, 10 P.2d 362, 363 (Or. 1932). Although the Constitution provides that states, with the consent of Congress, can enter into agreements with foreign nations, U.S. CONST, art. I, $\S 10, \mathrm{cl} .3$, the courts have narrowly interpreted the Compact Clause. The courts have frowned upon the states' ability to maintain continuous relations with foreign nations because such agreements would interfere with the supremacy of the federal government. See discussion infra regarding the courts' interpretation of the Compact Clause.

100. See U.S. v. Hooker, 607 F.2d 286, 289 (9th Cir. 1979); see generally First National City Bank v. Banco National de Cuba, 406 U.S. 759, 761 (1972).

101. Jennison, 39 U.S. at $\mathbf{5 7 0 .}$

102. Lane County v. Oregon, 7 Wall. 71, 76 (1869); Gregory v. Ashcroft, 501 U.S. 452, 457 (1991); Tafflin v. Levitt, 493 U.S. 455, 458 (1990).

103. U.S. Const. art. I, § 8, cl. 3 : Commerce Clause.

104. U.S. CONST. art. I, $\$ 10, \mathrm{cl} .1$ (absolutely prohibiting the states to enter into treaties with foreign nations); id. at art. I, $\$ 10, \mathrm{cl} .3$ (requiring states to obtain Congressional consent to enter into compacts with foreign countries).

105. In re Hansen's Estate, 281 N.Y.S. 617, 620-621 (N.Y. Sur. 1935); see also Zschernig v. Miller, 389 U.S. 429 (1968).

106. Jennison, 39 U.S. at 570.

107. Id.; Barron v. City of Baltimore, 32 U.S. 243 (1833).

108. 39 U.S. 540 (1840). 
crime in Canada and had escaped to Vermont. ${ }^{109}$ The Court found that by extraditing Holmes from Vermont to Canada, the governor was neither protecting his citizens nor exercising a valid police power. ${ }^{110}$ The court stated that Vermont, by assisting Canada under the principles of comity of nations, intruded upon the domain of the federal government's foreign affairs powers. ${ }^{111}$ Thus, the Court held that the agreement between Vermont and Canada was prohibited within the context of the federal government's control over foreign affairs, and therefore unconstitutional. ${ }^{112}$ Although this case was decided prior to the enactment of any federal statutes or treaties relating to extradition, it elucidates the premise that the authority to interact with foreign nations is vested in the federal government, and not the states.

In Sloan v. Baker, ${ }^{113}$ the Mayor of Portland visited Europe in order to establish diplomatic contacts with European municipalities. The Supreme Court of Oregon opined that cities do no possess any characteristics of a sovereign and thus can not aggrandize themselves with authority not given to them. ${ }^{114}$ The court, citing the federal Constitution's prohibition of state governments in establishing relations with foreign nations, ${ }^{115}$ declared that neither an expressed nor an implied authority existed "on the part of a municipality of a state to assume ambassadorial relations either with municipalities of other states or with foreign governments." 116 Therefore, states do not possess any foreign affairs powers. ${ }^{117}$

109. Jennison, 39 U.S. at 568 .

110. Id. at $568,569$.

111. Id. at 569; Comity is not a discretion afforded the state courts, but one possessed by the nationstates. Bank v. Earle, 13 Pet. 519, 589 (1839). Because comity is discretionary, it is not obligatory, and a nation-state can choose not to exercise their discretion. Hilton v. Guyot, 159 U.S. 113, 166 (1895).

112. Jennison, 39 U.S. at 568.

113. 10 P.2d 362 (1932). In Sloan v. Baker, the issue on appeal was whether the Mayor of Portland, Oregon, was entitled to payment of his salary for the sixty days that we was in Europe, and not in Portland. Id. at 363. Although this case is on the state court level, it exemplifies the doctrine of foreign relations preemption, the doctrine that neither a city nor a state has a mandate to exercise authority in the field of foreign affairs, a power directly vested in the federal government by the Constitution. See generally Koh, at 1824. But see Bilder, at 821, which argues that although the foreign affairs power is vested in the federal government, various states and municipalities have initiated relations with foreign nations and it is up to "Congress and the President to decide whether to preempt it." Id. at 830.

114. Sloan, 10 P.2d at 364.

115. U.S. CONST. art. I, \$10.

116. Sloan, 10 P.2d at 364 .

117. In practice, the states prohibition into the realm of foreign affairs is not considered absolute. In Clark v. Allen, 331 U.S. 503 (1947), the Supreme Court held that test was whether the intrusion by the states had "some incidental or indirect effect in foreign countries." Id. at 517 . In Clark, the court declared valid on its face a California probate reciprocity statute, which excluded non-resident alien legatees from taking a decedent's property, by either testamentary disposition or intestate succession, unless, similar procedures existed to afford United States citizens the same benefit in the foreign nation. 
The Supreme Court's stance on the Doctrine of Dormant Foreign Relations Preemption is represented in Zschernig v. Miller.$^{118}$ In Zschernig, the court held that Oregon's "Iron Curtain" statute was "an intrusion by the state into the field of foreign affairs which the Constitution entrusts to the President and the Congress." 119 The statute at issue allowed for property, which would have vested in German nationals by intestate succession, to escheat to the state before vesting unless the foreign nationals could prove, inter alia, that there existed a reciprocal right of inheritance in Germany. ${ }^{120}$ Justice Douglas stated that although states traditionally regulated intestate succession, if the state legislature "impair[s] the effective exercise of the Nation's foreign policy"121 it must be invalidated. ${ }^{122}$

In comparison, the ICSE provisions authorize states to enter agreements with foreign nations. ${ }^{123}$ Yet, the Constitution bars the states from enter into treaties with foreign nations. ${ }^{124}$ Furthermore, foreign relations power is directly

However, twenty years later, the Supreme Court's decision in Zschernig v. Miller, 389 U.S. 429 (1968) again established that any intrusion, regardless how indirect or incidental, by the state government in foreign affairs, have a direct effect on the federal government's ability to effectively administer their foreign relations power. Id. at 436. Justice Douglas enunciated that although matters of property is a area of law traditionally reserved to the states by the tenth amendment, international property law is a matter for the Federal government, not the state probate courts to decide. Id. at 438 . See also J. Stewart's concurrence stating the same premise. Id. at 443.

118. 389 U.S. 249 (1968). See also Koh, at 1847; Bilder, at 824-25.

119. Zschernig, 389 U.S. at 432.

120. Id. at 431 .

121. Id. at 440 .

122. Id. Justice Stewart, in concurrence, articulated that allowing states to act in matters of foreign affairs would be an invasion by the state where the Constitution only permitted the federal government to trespass. Id. at $\mathbf{4 4 2}$.

In contrast, Justice Harlan, concurring for other reasons, id. at 681-82, asserted that Oregon's "Iron Curtain" statute was not unconstitutional on its face and interprets the Court's decision as a call to find the statute unconstitutional when applied. Id. at 459 . Harlan oversimplifies the majority's opinion when he stated that the opinion rests on the premise that the statute's requirement of reciprocity and the fact that a foreign heir could inherit Oregon property would "involve the state courts in evaluation of foreign laws and governmental policies, and that this is likely to result in offense to foreign government." Id. at 459-60. Prior to any state court exercising their discretion, the statute's requirement of reciprocity frustrates the federal government's ability to negotiate with another country, in this case Germany, on matters of recognition of legatee rights.

Second, Harlan contends that the statute would not cause significant interference in foreign relations since the Court did not mention, nor did the record show that "any instance in which such an occurrence has been the occasion for a diplomatic protest, or, indeed, has had any foreign relations consequence whatsoever." Id. at 460. Harlan cites the fact that the government did not contend that the Oregon statute would interfere with the federal government's foreign relations. Id. Additionally, Harlan looks to the fact that the State Department has stated that such a State statute would have a minute effect on foreign relations and foreign policy. Id.

123. 42 U.S.C.A. $\$ 659 a$ (d) (West. 1998).

124. U.S. CONST. art. I, $\$ 10$. 
given to the executive branch for general purposes, ${ }^{125}$ and the legislative branch for economic purposes. ${ }^{126}$ Nor do state governments possess a right of passage into foreign affairs within their residual constitutional grant of power. ${ }^{127}$ Although states are sovereignties, similar to the decision in Sloan, states can not aggrandize themselves with authority implicitly denied to them by the federal Constitution. ${ }^{128}$ In early cases, such as Holmes, and later cases, such as Zschernig, the Supreme Court has articulated that the Framers did not intend for the states to have a foreign affairs power. ${ }^{29}$ Additionally, there exist no aperture within the Constitution's state prohibition clauses to imply that states even have a residual authority to enter into agreements with foreign nations. ${ }^{130}$ Comparatively, the ICSE provisions creation of a grant of power to the state government to negotiate child support agreements with foreign nations goes against the Constitutional text and the framer's intent of what constituted proper realms of state authority.

"No power under the [federal] government can make [any treaty entered into by a state] valid or dispense with the constitutional prohibition."131 The Court's interpretation of the constitutional limitations on state governments in Holmes and Zschernig, in addition to the similar treatment by a state supreme court in Sloan, illustrates that state governments can neither circumvent the limitations nor initiate agreements which would create an interference into United States foreign affairs. ${ }^{132}$

\section{B. Compact Clause}

A second issue which arises from the enactment of the ICSE provisions is whether the arrangements by the states with foreign nations goes so far beyond the scope of the Constitution's Compact Clause as to actually interfere with the nature of the federal structure of government. The current arrangements ${ }^{133}$

125. Id. art. II et seq; id. at art. II, $\S 2$, cl. 2.

126. Id. art. I, \& 8, cl. 3 ("To regulate Commerce with foreign Nations").

127. U.S. CONST. amend. $X$.

128. States can provide, within state constitutions, more protection to its citizens than are given to United States citizens within the federal constitution. Yet, states can not afford themselves more authority which is not enumerated within the federal constitution.

129. Holmes v. Jennison, 39 U.S. at 569; See also Hilton v. Guyot, 159 U.S. 113 (1895) (explaining that comity of nations can only exist between a federal government towards another nation's federal government, and is not a state court between a foreign nation.) Id. at 163-66; Bank v. Earle, 13 Pet. 519, 589 (1839) ("It is not the comity of the courts, but the comity of the nation.").

130. Cf. U.S. CoNST. art. I, $\$ 10$, cls. 1,3 with id. at amend. X.

131. Rhode Island v. Massachusetts, 37 U.S. 657, 724-725 (1838).

132. Id.

133. The Supreme Court in Virginia v. Tennessee, 148 U.S. 503, 520 (1893), defines the terms "compact" and "agreement." The term compact usually applies to formalistic contractual arrangements, while 
between states and foreign nations regarding international child support enforcement are parallel unilateral policy declarations, for example, agreements. ${ }^{134}$ The ICSE provisions represent congressional consent of these agreements. Yet, the contention lies in nature of these agreements as being beyond the framers' intent as permissible compacts, regardless of congressional consent.

The form of an agreement does not dictate whether it is a compact. The question rests on the impact of the arrangement on the federal government. ${ }^{135}$ The general test regarding what constitutes a compact between two sovereign entities $^{136}$ and whether it needs congressional consent was established at the close of the nineteenth century in Virginia $v$. Tennessee, ${ }^{137}$ which was substantially modified in United States Steel Corp. v. Multistate Tax Commission. ${ }^{138}$ The standard of review as to whether a compact falls under the Compact Clause of the constitution is (1) whether the agreement has an impact on the federal structure, ${ }^{139}$ and (2) whether the agreement tends to increase the political power of the state or interfere with areas of governance whose subject matters are under the exclusive control of the federal government. ${ }^{140}$

The first inquiry is whether the agreement has an impact on the federal structure. ${ }^{141}$ Not every agreement between two or more states is a "compact" requiring congressional consent. ${ }^{142}$ Agreements that are solely concerned with intrastate affairs or the health and safety of the state citizens ${ }^{143}$ would not pierce the federal government's domain. Few cases address the issue of a state entering into an agreement with a foreign nation. ${ }^{144}$ One early Supreme Court case which interprets the Compact Clause's application to such arrangements is Barron v. Baltimore. ${ }^{145}$ In that case, Barron, the owner of a wharf in

agreements refer to all stipulations between the two affected parties. Id. In this paper, I use the terms interchangeably, as the court has designated them to be used.

134. Gloria F. DeHart, Getting Over There, 9 FAM. ADvoc. 34 (1987) [hereinafter DeHart].

135. New Hampshire v. Maine, 426 U.S. 363, 369 (1976); Multistate Tax Comm'n, 434 U.S. at 470 71; see also Cuyler v. Adams, 449 U.S. 433, 440 (1981).

136. Sovereign entities can be either states or foreign nations.

137. Virginia v. Tennessee, 148 U.S. 503 (1893).

138. Multistate Tax Comm'n, 434 U.S. at 452.

139. Id. at 471.

140. Virginia, 148 U.S. at 518.

141. Multistate Tax Comm'n, 434 U.S. at 471.

142. Virginia, 148 U.S. at 518 . The Supreme Court lists illustrations of agreements between states where congressional consent would not be required to validate the agreement. Id. In addition, the court opines that "the terms 'compact' or 'agreement' in the Constitution do not apply to every possible compact or agreement between one state and another." $I d$.

143. Virginia, 148 U.S. at 518 . (noting various intrastate concerns which do not interfere with the federal structure).

144. Barron v. Baltimore, 32 U.S. 243 (1833); Holmes v. Jennison, 39 U.S. at 569.

145. 32 U.S. at 243. 
Baltimore's eastern harbor sued the city of Baltimore for damages caused when the city diverted waterways, which interfered with the operation of the docks. ${ }^{146}$ In dicta, Justice Marshall asserted that the Constitution expressly placed limits on the state government in certain subject matters, as listed in Article I, Section 10 of the Constitution. ${ }^{147}$ He elucidated the issue regarding a state's ability to compact with foreign countries by declaring that such arrangements interfere with the exclusive power of the federal government to enter into treaties. ${ }^{148}$ Yet, Marshal acknowledged that compacts amongst the several states do not conflict with the framers' intent and purpose for the clause. ${ }^{149}$ The premise of Marshall's stance lies in the fact that if a state government acted, on the local level, in the making of arrangements with foreign nations, then such action would interfere with the federal government's authority of coordinating efforts, on a national level, for the common good of all citizens. ${ }^{150}$ Since the limitation are expressively stated in the Constitution, the court found there was no room for interpretation as to any other meaning. ${ }^{151}$ Thus, the court stated that there did not exist any convincing evidence to ignore the expressed limits the Constitution has placed on the state legislature. ${ }^{152}$

Similarly, in Virginia $v$. Tennessee, ${ }^{153}$ Virginia wanted the court to set aside a compact entered into by Virginia and Tennessee to establish their respective borders for lack of congressional consent. ${ }^{154}$ The case dealt with determining what types of compacts need congressional consent. ${ }^{155}$ Justice Field, citing Justice Story, ${ }^{156}$ expressed that where treaties are political in nature, compacts apply to subjects which "might be deemed mere private rights of sovereignty." 157 Furthermore, just as Congress can give consent to validate a compact, Congress can also bar states from entering into compacts. ${ }^{158}$ Certain

146. See id. The issue centered around whether the actions of the municipality constituted a taking under the fifth amendment of the United States Constitution. Although, The case was dismissed for lack of jurisdiction, the court did address the issue of the application of the Compact Clause to state agreements with foreign nations. Id. at $249,251$.

147. See id. at 249. The purpose of Article I, $\$ 10$ of the Constitution was to "restrain state legislation on subjects entrusted to the government of the union, in which the citizens of all the states are interested." id.

148. Barron, 32 U.S. at 249.

149. Id.

150. Id.

151. Id.

152. Id.

153. Virginia, 148 U.S. at 503.

154. Id. at 517 .

155. See id. at 518-519.

156. J. STORY, COMMENTARIES ON THE CONSTTIUTION OF THE UNITED STATES $\$ 1403$ (R. Rotunda \& J. Nowak eds. 1987).

157. Virginia, 148 U.S. at 519.

158. Id. at 519-520. 
subject matters belong to the federal government as a general right of federal sovereignty. ${ }^{159}$ In addition, these rights also belong to the state governments, unless the right has been ceded to the federal government by the federal constitution. ${ }^{160}$

If the scope of the Compact Clause encompasses those agreements which tend to increase the political power of the states, thus "encroach[ing] upon or interfere[ing] with the just supremacy of the United States," 161 then agreements regarding the enforcement of international child support would fall under the clause. Even if the ICSE provisions operate as congressional consent, the legislative history of the ICSE provisions acknowledges the fact that states do not have the power to enter into treaties. ${ }^{162}$ Likewise, the United States Constitution prohibits states from entering into any treaty, ${ }^{163}$ and requires states to gain congressional consent to enter into any agreement or compact with another state or foreign power. ${ }^{164}$

The permissive language within the ICSE provision would imply that the statute's intent is to consent to the agreements between states and foreign nations regarding international child support enforcement. ${ }^{165}$ If the ICSE provision constitutes congressional consent, the provision would make any arrangements made by a state with a foreign nation a matter of federal law. ${ }^{166}$ Similarly, provisions of a treaty have equal footing with acts of Congress. ${ }^{167}$ When a federal law and a provision of the United States Constitution, in this case the Compact Clause, are in conflict with one another, the Constitution, as the supreme law of the land will always prevail. ${ }^{168}$ Therefore, the ICSE provision as federal law can not permit states to enter into agreements with foreign nations. The courts in Barron and Virginia expressed that the framers'

159. Id. at 525 .

160. Id.

161. Cuyler v. Adams, 449 U.S. 433, 440 (1981); Multistate Tax Comm'n, 434 U.S. at 485 (White, J., dissenting); See also McHenry v. Brady, 163 N.W. 540, 544 (N.D. 1917).

162. H.R. REP. No. 104-430, at 44 (1995); H.R. REP. No. 104-350, at 44 (1995); Pub. L. No. 104193, § 39, 110 Stat. 2105 (1996); 141 CONG. REC. H15317-01, H15427 (1995); 141 CONG. REC. H12509-01 (Pt. 2), H12976 (1995); See also U.S. CoNST. art. I, \& 10, cl. 1.

163. U.S. CONST. art. I, \&10, cl. 1 (state treaty prohibiting clause).

164. U.S. CoNST. art. I, $\$ 10, \mathrm{cl} .3$ (compact clause).

165. 42 U.S.C.A. $\$ 659$ a(d) (West 1998). "States may enter into reciprocal arrangements for the establishment and enforcement of support obligations with foreign countries that are not the subject of a declaration [by the State Department], to the extent consistent with Federal law." Id.

166. Cuyler, 449 U.S. at 439 n. 7. Under the "Law of the Union" Doctrine, if an interstate agreement has congressional approval it becomes federal law. See also Delaware River Joint Toll Bridge Comm'n v. Colburn, 310 U.S. 419, 427-28 (1940); Pennsylvania v. Wheeling \& Belmont Bridge Co., 54 U.S. (13. How.) 518,566 (1852).

167. Asakura v. City of Seattle, Washington, 265 U.S. 332, 341 (1924); United States v. The Peggy, 5 U.S. 103 (1801).

168. Marbury v. Madison, 5 U.S. 137 (1803). 
intent did not allow for continuous on-going agreements between the states and any foreign nations. Such agreements would interfere with the delicate nature of the federal system of government. Thus, Congress' grant to the states of the authority to negotiate agreements with foreign nations concerning child support enforcement goes against the constitutional limitations placed upon and residual powers vested in the government of the several states.

\section{Foreign Commerce Clause}

Article I, Section 8 of the United States Constitution states that "Congress shall have the Power ... To regulate Commerce with foreign Nations, and among the several States, and with Indian Tribes."169 Since 1937, when the Supreme Court decided NLRB v. Jones \& Laughlin Steel Corp.,${ }^{170}$ the court has broadened its recognition of Congress' plenary powers under the Commerce Clause. NLRB marked the commencement of a period of extreme judicial deference to the legislature. ${ }^{171}$ It was not until the Supreme Court's decision in United States $v$. Lopez, ${ }^{172}$ that the judiciary began to reevaluate Congress' assertions of authority under the Commerce Clause.

Although foreign affairs power is vested primarily in the executive branch, only Congress has the power to regulate foreign commerce. ${ }^{173}$ In Hodel $v$. Virginia Surface Mining \& Reclamation Ass' $n,{ }^{174}$ the Supreme Court developed a two-prong test in determining whether Congress has exceeded its authority under the Commerce Clause. ${ }^{175}$ To evaluate the constitutionality of Congress' consent to states to enter into agreements with foreign nations, the Court would first have to determine whether a rational basis exists to conclude that the

169. U.S. CoNST. art. I, \& 8, cl. 3.

170. NLRB v. Jones \& Laughlin Steel Corp., 301 U.S. 1 (1937). In NLRB, the court upheld the National Labor Relations Act against a Commerce Clause challenge. Id. at 36-8. In doing so, the court held that Congress may regulate intrastate commerce activities which have a substantial effect on interstate commerce as a prophylactic against burdens on interstate commerce. Id. at 37.

171. See United States v. Darby, 312 U.S. 100 (1941) (upholding the Fair Labor Standards Act); Wickard v. Filburn, 317 U.S. 111, 128-29 (1942) (upholding the Agricultural Adjustment Act of 1938). In Wickard, the application of the Commerce Clause was stretched to its limits. The court, by upholding the act, permitted Congress to regulate local production and local consumption of wheat by a farmer because the aggregate effects of taking the wheat out of commercial circulation would substantially effect interstate commerce.

See also United States v. Lewis, 936 F. Supp. 1093, 1096 (D. R.I. 1996) (noting that "the Supreme Court had not invalidated a federal statute as exceeding Congress' authority under the Commerce Clause for over fifty years" until the Lopez decision).

172. Lopez, 115 S. Ct. at 1624.

173. United States v. Guy W. Capps, Inc.; 204 F.2d 655 (4th Cir. 1953), aff d, 348 U.S. 296 (1955).

174. Hodel v. Virginia Surface Mining \& Reclamation Ass'n, 452 U.S. 264 (1981).

175. See id. at 276. 
regulated activity substantially effects interstate or foreign commerce. ${ }^{176}$ If a rational basis exist, the court would then look to see whether the specific regulation is reasonably adapted to the goals permitted by the Constitution. ${ }^{177}$

In Lopez, the Supreme Court established three broad categories of activity which Congress can regulate under the Commerce Clause: (1) the channels of interstate commerce; (2) the instrumentalities of interstate commerce; and (3) those activities having a substantial relation to interstate commerce. ${ }^{178}$ Chief Justice Rehnquist declared "that the proper test requires an analysis of whether the regulated activity 'substantially effects' interstate commerce."179 The Lopez decision has been used as the judicial standard in determining the outer limits of the Commerce Clause. ${ }^{180}$ Given the language in the ICSE provisions, test two and test three seem to address the issue of whether the designation to the state government of a right to enter into an agreement with a foreign nation is with in Congress' Commerce Clause power.

Goods which enter into the stream of commerce are immune from state or local taxation, so long as, the goods remain in the stream of commerce. ${ }^{181}$ Currently, the federal courts are spilt as to whether payment of child support orders are considered "goods" and thus can be regulated by Congress under the Commerce Clause. ${ }^{182}$ The standard for regulation of commerce is whether the activity substantially affects interstate commerce. ${ }^{183}$ Any economic activity by the states which substantially effects or places a direct burden on Congress' enumerated power to regulate foreign commerce can be regulated by Congress under the Commerce Clause. ${ }^{184}$

The economic or commercial impact of the activity on interstate commerce dictates whether Congressional regulation is permissible, not the nature of the

176. Id.

177. Id.

178. United States v. Lopez, 115 S. Ct. at 1629-30.

179. Id. at 1630 .

180. See Unites States v. Ganaposki, 930 F. Supp. 1076, 1078-79 (M.D. Pa. 1996) (analyzing the constitutionality of the Child Support Recovery Act in light of Lopez); Lewis, 936 F. Supp. at 1097-1100 (analyzing the constitutionality of the Child Support Recovery Act using Lopez's categorical analysis).

181. See Eureka Pipe Line Co. v. Hallanan, 257 U.S. 265 (1921).

182. Compare Lewis, 936 F. Supp. at 1096 (asserting that regulation by Congress of interstate child support payments is a regulation of channels of interstate commerce) with United States v. Parker, 911 F. Supp. 830 (E.D. Pa. 1995), (arguing that Congress lacked the authority to regulate failure to pay child support orders because unpaid money in such cases did not constitute a "good"). See also United States v. Ganaposki, 930 F. Supp. 1076, 1082 (M.D. Pa. 1996) (noting that the Third Circuit, in United States v. Bishop, 66 F.3d 569 (3rd Cir. 1996), defines "commerce" under the Commerce Clause quite expansively).

183. See Ganaposki, 930 F. Supp. at 1082.

184. See DiSanto v. Pennsylvania, 237 U.S. 34 (1927); United States v. Wrightwood Dairy, 315 U.S. 110, 119 (1942); Cuban Steamship v. Fitzpatrick, 66 F. 63 (E.D. La. 1895). 
activity. ${ }^{185}$ The majority of the courts hold that regulation of child support enforcement is a constitutional exercise of Congress' Commerce Clause power. ${ }^{186}$ Payment of child support constitutes commerce because the parent who does not fulfill his or her obligation to pay receives an economic gain by withholding such funds, at the same time there exist an economic loss to the child who does not receive the needed money. ${ }^{187}$ Under the analysis that Congress has the authority to regulate all channels of interstate commerce, ${ }^{188}$ payment of child support payments is an economic activity which has a substantial effect on interstate commerce. Thus by analogy, international child support payments would have an equivalent effect on foreign commerce. Therefore, if payment of child support is considered a "good," then any agreement by the states with a foreign nation could impair a "good" traveling with in the stream of foreign commerce. Congress has plenary powers over foreign commerce. Yet, the taxing harm caused by the state agreements with foreign nations would be left entirely to the whim of state government and its legislature.

In Lopez, the Supreme Court struck down a federal statute which regulated the possession of a gun on school property. ${ }^{189}$ After presenting a history of judicial treatment of the Commerce Clause, ${ }^{190}$ Justice Rehnquist, writing the opinion for the court, stated that possession of a hand gun on school property did not constitute an economic activity that might substantially effect interstate commerce. ${ }^{191}$ The court noted that the invalid statute lacked two things. First, the statute failed to provide a jurisdictional element, connecting the regulated activity with interstate commerce. Second, the statute lacked any mention, in its text or legislative history, of its substantial impact on interstate commerce. ${ }^{192}$

185. See Ganaposki, 930 F. Supp. at 1082; United States v. Bishop, 66 F.3d 569, 581 (3rd. Cir. 1996).

186. Currently nine district courts and the Second Circuit have upheld a federal statute which criminalizes the non-payment of child support as constitutional. Only four district courts have found that the statute is beyond Congress' Commerce Clause power.

187. See United States v. Sage, 906 F. Supp. 84, 90 (D. Conn. 1995); Lewis, 936 F. Supp. at 1099.

188. See United States v. Nichols, 928 F. Supp. 302, 314 (S.D.N.Y. 1996). Since payment often occurs by mail, wire, or electronic transfer of funds, these instrumentalities are all included in Congress' broad definition of interstate commerce. Id.

189. Lopez, $115 \mathrm{~S}$. Ct. at 1634. See discussion infra p. 1634 (providing a more detail analysis of the case).

190. Lopez, 115 S. Ct. at $1627-30$.

191. See id. at 1634 .

192. See id. If these two elements were included, the court could have found that the inclusion was merely a pretext to validating the law under the Commerce Clause. Yet, the pretext argument is difficult to prove.

The Lopez case merely adds to the pile of uncertainty regarding what Congress can regulate. Unlike the historical test of direct or indirect effects on interstate commerce, the substantial effects test acknowledges 
Similar to the statute in Lopez, the ICSE provisions lack the necessary legislative history to create a nexus between international child support enforcement and foreign commerce. ${ }^{193}$ It can be asserted that Congress has the authority to regulate payment of international child support orders. ${ }^{194}$ However, what is being challenged is the statute's grant of authority to the state governments to regulate an activity that has a substantial effect on foreign commerce. Subsection (d) of the first ICSE provision ${ }^{195}$ says that "states may entered into reciprocal arrangements for the establishment and enforcement of support obligations with foreign countries."196 Neither the statute nor the legislative history indicates why granting the states government authority to enter into such agreements has a diminishing effect on foreign commerce. ${ }^{197}$ The patent effect of subsection (d) is a grant by Congress to the state government to do indirectly what Congress can not do directly, enter into treaties with foreign nations. ${ }^{198}$ The latent effect of subsection (d) is permission given to the states to regulate foreign commerce. Enforcement of international child support claims does substantially effect foreign commerce. The abdication of authority by Congress to the states contradicts the plenary power of Congress to regulate under the Commerce Clause. Congress can not regulate all aspects of human life. ${ }^{199}$ Yet, in those areas of activity where Congress can regulate, Congress should not be able to haphazardly relinquish its authority to the state government if such an action would allow states to set foreign policy and regulate foreign commerce.

It was not the intention of the framers to give any constitutional recognition to the state government as having a "reserved power" in the area of foreign commerce. Congress' control over foreign commerce has a tremendous impact on foreign policy. It can be inferred that any dissemination of this control to the state government would permit the states and local governments to also construct United States foreign policy. Congress has a right, under the foreign

Congress' plenary power under the Commerce Clause but at the same time eroding the limits on Congress' inability to usurp areas of law which have traditionally been under the police power of the states.

193. See discussion following supra notes 44-48.

194. But see United States v. Parker, 911 F. Supp. 830 (E.D. Pa. 1995), (arguing that Congress lacks the authority to regulate failure to pay child support orders because unpaid money in such cases did not constitute a "good").

195. 42 U.S.C.A. § 659a(d) (West 1998).

196. See id.

197. If Congress regulates, they must show that the regulated activity has a substantial effect on interstate commerce. Conversely, if the state regulates, it must show that the effect on interstate commerce was so minute enough to not require Congressional regulation of the activity. But see Wickard v. Filburn, were the court upheld a federal regulatory statute because the aggregate effects of the regulated activity had a substantial effect on interstate commerce. 317 U.S. at 111.

198. See discussion supra note 197.

199. See Lopez, 115 S. Ct. at 1632. 
commerce clause, to regulate international child support enforcement. However, the statute's appointment to state governments, of an equivalent right to enter into agreements with foreign nations on the issue of international child support enforcement, goes against the foreign commerce clause relations to the state.

\section{UNITED STATES V. LOPEZ: IT'S EFFECT ON THE INTERNATIONAL CHILD SUPPORT ENFORCEMENT DEBATE}

One of the main purposes of this paper is to elevate the discussion in whole or in part of the possible invalidity of the ICSE provisions. One way to go about this mission is to not only present an argument that Congress has the authority to act but also to assert that Congress lacks the authority to regulate international child support enforcement. Before United States v. Lopez, Congress' regulatory power under the Commerce Clause was nearly omnipotent for over fifty years. During that time period, Congress passed laws dealing with problems on a national scope, which were morally based and Commerce Clause authorized. ${ }^{200}$ Since Lopez, the Supreme Court's deference to Congress has waned, replaced instead with a demand that Congress justify its use of the Commerce Clause to regulate state activity. Utilizing the analysis by the Supreme Court in Lopez, it can be argued that Congress has no actual or inherent authority to regulate international child support enforcement claims.

In Lopez, a 12th grader was arrested and charged under the Gun-Free School Zones Act of $1990,{ }^{201}$ for possession of a gun while on school property. The Supreme Court held that the statute exceeded Congress power under the Commerce Clause. ${ }^{202}$ The court, affirming the Fifth Circuit's decision, declared the federal statute lacked two key components. ${ }^{203}$ First, the statute failed to state whether the regulated activity substantially effected interstate commerce. ${ }^{204}$ In the alternative, if the regulated activity had been an essential part of a larger regulatory scheme where by without congressional regulation the scheme would severely burden interstate commerce then the statute may have been saved. ${ }^{205}$ However, the court concluded that this was not the case..$^{206}$ The court found that the statute's regulation of gun possession on or near school

200. See Heart of Atlanta Motel Inc. v. United States, 379 U.S. $241-53$ (1964) (regulation of inns and hotels which catered to tourists in order to promote racial integration). See also JnL E. HASDAY, Federalism and the Family Reconstructed, 45 UCLA L. REV. 1297, 1310 (1998) (examining the Violence Against Women Act of 1994).

201. 18 U.S.C. § $922(q)(1)(A)(1988)$.

202. Lopez, 115 S. Ct. at 1634 .

203. See id. at $1630-1631$.

204. See id.

205. See id. at 1631.

206. See id. 
grounds had nothing to do with commerce. ${ }^{207}$ Furthermore, the regulation had no aggregate effect on interstate commerce. ${ }^{208}$

In Wickard v. Filburn, ${ }^{209}$ the court looked to what could be considered the outer limits of Congress' ability to control interstate commerce to support its finding. In Wickard, a farmer who had used his land to.grow wheat for his personal consumption was fined for violating the Agricultural Adjustment Act of $1938 .^{210}$ The government argued that because the goal of the legislature was to increase the market price of wheat, the aggregate effects of "home-consumed wheat would have a substantial influence on price and market conditions."211 Even though Filburn's wheat was never sold on the grain market, the court upheld the federal statute because by growing his own wheat, Filburn would have no need to buy wheat. ${ }^{212}$ The aggregate effect of farmers similarly situated as Filburn would cause demand for wheat to decrease, thus directly effecting wheat prices. ${ }^{213}$

International child support claims have a substantial effect on foreign commerce. Payment or failure to pay international claims effect foreign commerce. If commerce is intercourse, ${ }^{214}$ then an economic activity that effects international borders is foreign commerce. When a foreign parent pays child support, it allows for the child to purchase various sustainable items. In contrast, when a parent does not pay child support, it creates an economic loss to both the child and the effected economy. Yet, Justice Thomas, in his concurrence, averred that "the power to regulate 'commerce' can by no means ... empower the Federal government to regulate marriage ... throughout the 50 states."215 Thus, what is still left undecided is whether Congress can regulate international child support. ${ }^{216}$

Next, the court expressed that the statute should state a jurisdictional element demarcating the nexus between interstate commerce and the regulated

207. Lopez, 115 S. Ct. at 1630-31.

208. See id. at 1631.

209. Wickard v. Filburn, 317 U.S. 111 (1942).

210. Id. at 128.

211. Id.

212. See id.

213. See id. If the farmer grows his own wheat, then he has no need to buy wheat, thus decreasing the demand for wheat on the open market. When the farmer decides not to sell his wheat but use it for personal consumption, it results in a decrease in supply of wheat in the open market.

214. See Gibbons v. Ogden, 22 U.S. 1 (1824). "Commerce, undoubtedly, is traffic, but it is something more: it is intercourse. It describes the commercial intercourse between nations and parts of nations, in all its branches, and is regulated by prescribing rules for carrying on that intercourse." Id.

215. Lopez, 115 S. Ct. at 1642 (Thomas, J., concurring).

216. But see id. (Thomas, J., concurring) ("Any interpretation of the Commerce Clause that even suggests that Congress could regulate such matters is in need of reexamination."). 
activity. In United States $v$. Bass, ${ }^{217}$ such a connection was established. In Bass, the court upheld a federal statute that criminalized the receiving, possessing, or transporting of any firearm in commerce or affecting commerce. ${ }^{218}$ "The Court interpreted the possession component of [the statute] to require an additional nexus to interstate commerce both because the statute was ambiguous and because 'unless Congress conveys its purpose clearly, it will not be deemed to have significantly changed the federal-balance.",219 Thus, to be successful, the defender of the statute must demonstrate not only that the regulated activity occurred but also that there exist a nexus between the regulated activity and interstate commerce. Such expressed jurisdictional element might limit Congress' reach to a finite set of person or things that have an explicit connection with or effect on interstate commerce. ${ }^{220}$

Courts have looked to the expressed legislative history and committee notes for clarification. Even though legislative findings are not necessary, ${ }^{221}$ they enable the court to interpret the legislative intent of the statute. ${ }^{222}$ Yet, in the case of the ICSE provisions such legislative findings are essential because, similar to the statute in Lopez, the ICSE provisions addresses a never before promulgated issue. ${ }^{223}$ Thus, the "prior federal enactments or Congressional findings [do not] speak to the subject matter ... or its relationship to interstate commerce."224 However, the legislative history and the committee notes of the ICSE provisions do not state the requisite nexus with interstate commerce. The issue is whether Congress can regulate, with out more, international child support enforcement. ${ }^{225}$ Under the Bass model, a clear congressional intent must be shown. ${ }^{226}$ In the ICSE provisions it was not.

In Lopez, the court determined that if the government's argument was to be accepted, it would hamper the court's ability to limit Congress' regulatory authority of subjects traditionally under the state's police power. ${ }^{227}$ Federal

217. United States v. Bass, 404 U.S. 336 (1971).

218. Id. at 337; see also Lopez, $115 \mathrm{~S}$. Ct. at 1631 .

219. Lopez, 115 S. Ct. at 1631 (quoted in Bass, 404 U.S. at 349).

220. See id.

221. Perez v. United States, 402 U.S. 146, 156 (1997) ("Congress need not make particularized findings in order to legislate."); Lopez, $115 \mathrm{~S}$. Ct. at 1631.

222. Lopez, 115 S. Ct. at 1631-32.

223. Pub. L. No. 104-193, $\$ 39,110$ Stat. 2105 (1996) (indicating that prior to the passage of the ICSE provisions, no legislation existed on the issue of international child support enforcement).

224. Lopez, 115 S. Ct. at 1632.

225. See id. at 1631.

226. See Bass, 404 U.S. at 337.

227. See Lopez, $115 \mathrm{~S}$. Ct. at 1632 ("[I]t is difficult to perceive any limitations on federal power, even in areas such as criminal law enforcement or education where states historically have been sovereign"). Justice Rehnquist, in his decision for the court, criticizes Justice's Breyer's dissent as lacking limits because it would allow any activity to be economic in nature and thus under Congress' regulatory control. 
police power does not exist in the Constitution. ${ }^{228}$ "The Constitution mandates this uncertainty [of which government controls which subject matters] by withholding from Congress a plenary police power that would authorize enactments of every type of legislation."229 Since the ICSE provision deals with family law, one of the areas under a state's police power, it can be averred that Congress lacks the requisite power to regulate international child support enforcement under the Commerce Clause.

\section{CAN THE ICSE PROVISIONS STAND AS AN EFFECTIVE TOOL IN INTERNA- TIONAL CHILD SUPPORT ENFORCEMENT?}

All legislation is presumed constitutional. Yet, "[i]f [Congress] were to make a law not warranted by any of the powers enumerated, it would be considered by the judges as an infringement of the Constitution which they are to guard ... They would declare it void."230

\section{A. The ICSE Provisions Create Legal Quagmires}

The Constitution absolutely prohibits states from entering into treaties with foreign nations. ${ }^{231}$ The significance of such a limitation on state government was to prevent local interference into foreign affairs. As mentioned, traditionally the Supreme Court has held that any action by a state with a foreign nation would invoke this constitutional prohibition. ${ }^{232}$ Yet, recently the court had been of two differing positions. First, if the subject matter has a high probability of becoming a subject of international dispute then the federal government has paramount authority in and power over the subject matter. ${ }^{233}$ In United States v. California, ${ }^{234}$ the conflict centered around whether California could control oil reserves located within the boundary of the State's three mile territorial waters. ${ }^{235}$ The court held that such authority over petroleum commerce would severely affect the nation's ability to engage in commerce with other nations and the stability of global peace. ${ }^{236}$ The court

228. See id. at 1633.

229. See id.

230. THE FEDERALIST No. 3, at 553 (John Marshall); See also Lopez 115 S.Ct. at 1650 n. 9 (Thomas, J., concurring).

231. U.S. CoNST. art. I, $\$ 10$, cl. 1.

232. Jennison, 39 U.S. at 540 (holding that New York had no right to capture and relinquish a fugitive to Canada).

233. United States v. California, 332 U.S. 19 (1947).

234. Id.

235. See id. at 28-29.

236. See id. 
ruled that control of the oil reserves was the exclusive jurisdiction of the federal government and not that of the California State government. ${ }^{237}$

On the other hand, the court has found the treaty prohibiting clause did not prevent a state from regulating its citizens' fishing activity outside the state's territorial waters. ${ }^{238}$ In Skiriotes $v$. Florida ${ }^{239}$ the court held that if Florida's action did not directly conflict with federal legislation, then Florida could exercise its police power to regulate its citizens' behavior on the high seas.

Comparatively, the agreements by the states do have a potential for international conflict. Early agreements between states and foreign nations were not binding on both parties. ${ }^{240}$ Furthermore, it can be inferred from Gloria DeHart's article ${ }^{241}$ that the arrangements between the states and the foreign nations were wrought with problems because of lack of reciprocity on the part of the state and the inability or unwillingness of foreign courts to enforce state judgments. ${ }^{242}$ Besides Canada, Great Britain no longer recognized an extended definition of state to include individual states, thus requiring a nation to nation reciprocity of recognizing of child support orders. ${ }^{243}$ In West Germany, a semiprivate agency, and not the federal government, ${ }^{244}$ established an arrangement with California regarding enforcement of child support orders. ${ }^{245}$ Although the individual states established a de facto reciprocity ${ }^{246}$ system with Germany and the other nations, the ICSE provision would still require both the reciprocating nation and the United States to establish reciprocity by governmental declaration. ${ }^{247}$ The notion of de facto reciprocity presupposes that de jure reciprocity would be an agreement established by treaty between the initiating country and the responding country. Despite the fact that within several foreign countries legislation has been passed to recognize agreements with individual states and to establish reciprocity with the state, ${ }^{248}$ with the United States such legislature,

237. See id. at 29.

238. Skiriotes v. Florida, 313 U.S. 69 (1941).

239. Id.

240. See DeHart, supra note 134, at 94 n. 26 (exclaiming that although Canadian courts would enter a final judgement on child support order originating from an American state, the Canadian court still required from the state government some assurance of reciprocity to be attached to the original order).

241. Id.

242. Id. at 94-99.

243. Id. at $95 \mathrm{n} .29$.

244. Id. at 96. According to DeHart, under German law the German government could not participate officially. DeHart, supra note 134, at 96.

245. Id. at 97 (describing an agreement between France, New York, and California).

246. Id. at 102 (defining de facto reciprocity as recognition of a foreign other with out the formalities of a treaty).

247. See 42 U.S.C. \& 659a(a).

248. See DeHart, supra note 134 , at $98-99$. 
as embodied in the ICSE provisions, may not be legally invalid against our Constitution.

Similar to California, the individual arrangements by the state and the foreign governments on international child support enforcement lay the foundation for potential international disputes. Unlike Skiriotes, arrangements between states and foreign nations do affect the sovereign authority of the United States to negotiate with other nations on this subject matter. If the United States had been a signatory to any of the United Nations treaties on the subject of international child support enforcement, the states participation and the ICSE provisions would be considered "necessary and proper" implementation in the enforcement process. ${ }^{249}$ However, the United States is neither a signatory to or has never negotiated with any nation in the area of international child support enforcement. The negotiation by the state governments and the resultant de facto reciprocity between the state and foreign nations can infer a treaty like relationship between the two parties.

How the courts have interpreted the Compact Clause creates a second argument as to why agreements between state and foreign nations run afoul of the Constitution. Aside from the necessity of Congressional consent, the original inherent right of states to make compacts was not relinquished under the Constitution. ${ }^{250}$ The formation of compacts by states was to be equivalent to sovereign nations forming treaties. ${ }^{251}$ The significance of the distinction between the treaty prohibiting clause and the compact clause was stated by the Supreme Court in Holmes v. Jennison. 252

[T] he use of all of these terms, "treaty," "agreement," and "compact" show that it was the intention of the framers of the Constitution to use the broadest and most comprehensive terms; and that they anxiously desired to cut off all connection or communication between a State and a foreign power; and we shall fail to execute that evident intention, unless we give to the word "agreement" its most extended signification; and so apply it as to prohibit every agreement, written or verbal, formal or informal, positive or implied, by the mutual understanding of the parties. ${ }^{253}$

249. Under the Federal Constitution's Necessary and Proper Clause, U.S. CoNST, art. I, § 8, cl. 18, federal statutes enacted in accordance with treaties or conventions the United States is signatory to are considered "necessary and proper" toward the execution of the treaty.

250. Poole v. Fleeger, 36 U.S. 185, 209 (1837).

251. Hinderlider v. La Plata Co., 304 U.S. 92, 104 (1938) ("The Compact adapts to our Union of sovereign States the age-old treaty-making power of independent sovereign nations."); Rhode Island $v$. Massachusetts, 37 U. S. at 725.

252. Poole, 39 U.S. at 540.

253. See id. at 570-572. 
Yet, the court later established the test for congressional consent as any agreement that had a tendency to increase the political power of the state government or to encroach upon the just supremacy of the United States. ${ }^{254}$ Agreements between the states and the foreign nations may not necessarily increase the political power of the state government, but it does interfere with the just supremacy of the United States' ability to act in the international affairs. ${ }^{255}$ Even if the ICSE provision constituted congressional consent, if challenged, it is possible to argue that the authority granted to the states is of such a nature that it would so severely hamper American foreign diplomacy as to cause conflict of interest between the state government and the federal government. This conflict of interest between the dual sovereigns, similar to California, could eventually lead to conflict on an international level. It can be inferred that agreements between the state and foreign nations should be within the jurisdiction of the federal government in order to avoid any potential problems in the international community. Comity is defined as:

the recognition which one nation allows within its territory to the legislative, executive, or judicial acts of another nation, having due regard both to international duty and to the rights of its own citizens or of other person who are under the protection of its laws. ${ }^{256}$

Comity is not a discretion afforded to state courts, but one possessed by nationstates. ${ }^{257}$ Because comity is discretionary, it is not obligatory, and nation-states can choose to exercise it at their discretion. ${ }^{258}$ Since 1840, when Holmes was decided, the more recent court decisions regarding comity have referred back to the Holmes' definition of the nature of the doctrine. ${ }^{259}$ Comity is more likely to be considered non-obligatory in nature on the federal court level as seen in the Holmes ${ }^{260}$ and limited to the parties who are signatories of the compact, as in Virginia $v$. Tennessee. ${ }^{261}$ Under the ICSE provisions, agreements between the state government and foreign nations places a burden on states that are not party to the agreement to assist in requests by foreign nations. ${ }^{262}$ The statute

254. See Virginia, 148 U.S. at 518; Multistate Tax Comm'n, 434 U.S. at 452.

255. See Hooker, 607 F.2d at 289 (proclaiming that the state and federal governments have no precedence of intergovernmental cooperation in international relations and states have no authority to conduct the international affairs of the United States).

256. See DeHart, supra note 134, at 92; See also Hilton, 159 U.S. at 166 . The duty that exists is an international duty to respond, not a domestic duty.

257. Bank v. Earle, 38 U.S. 519,589 (1839).

258. Hilton, 159 U.S. at 166.

259. See id.

260. Holmes, 39 U.S. at 569.

261. Virginia v. Tennessee, 148 U.S. 503 (1893).

262. See 42 U.S.C. § 654 II 32(A). 
specifically states that request "by a foreign reciprocating country ... which the States has an arrangement ... shall be treated as a request by a state." ${ }^{263}$ Such a statement can be construed as use of the Full Faith and Credit Clause to implement foreign support orders in non-party states.

From this analysis, the statute can be challenged as creating an obligatory nature to the principle of comity by forcing the state executive branch to implement federal policy. ${ }^{264}$ In addition, a non-custodial parent can contend that the statutes require non-contracting states to be party to reciprocal agreements whose terms they were not able to negotiate. ${ }^{265}$ Both the doctrine of comity and recognition of foreign judgments by the courts are discretionary in nature. If that is the case, then the statute's imposition of a duty on state courts to accept international foreign judgments goes against the legal premise of foreign judgments being merely prima facie evidence that a debt exists. The legal effect of the statute would be to create a recognition and obligation to pay in states who have adopted the UFMJRA, ${ }^{266}$ and thus making those states party to another state's reciprocal agreement with a foreign nation. In total, the statute creates a lack of accountability in the federal government ${ }^{267}$ by impressing upon and creating in the states a duty of care they would not naturally posses. ${ }^{268}$

\section{B. The ICSE Provisions Delegation of Power to States Should be Chal- lenged}

Although an early court case may have stated an absolute concept that "legislative power can not be delegated," 269 the court has on many occasions sustained congressional delegation of power to federal agencies. ${ }^{270}$ There exists a de facto recognition by the court of Congress' ability to delegate its authority in order to resolve specific problems. "Delegation by Congress has long been

263. See id.

264. See Printz v. United States, 117 S. Ct. 2365, 2383 (1997) (finding that Congress has no authority in forcing state officials to implement federal policy).

265. Rhode Island v. Massachusetts, 37 U.S. at 748 (stating that states should be made party to any compact or agreement which effects their territory or citizens).

266. By adopting the UFMJRA, states are not allowed to recognize foreign judgments pertaining to marital situations.

267. See Printz, 117 S. Ct. at 2382.

268. Edgar v. MITE Corp., 457 U.S. 624, 644 (1982) ("The State has no legitimate interest in protecting nonresident[s]").

269. See United States. v. Shreveoprt Grain \& Elevator Co., 287 U.S. 77, 85 (1932).

270. See, e.g., New York Central Securities Co. v. United States, 287 U.S. 12, 25 (1932) (Interstate Commerce Commission); Federal Radio Comm'n v. Nelson Bros. Bond \& Mortgage Co., 289 U.S. 266 (1933) (Federal Radio Commission); National Broadcasting Co. v. United States. 319 U.S. 190 (1943) (Federal Communication Commission); Mistretta v. United States, 488 U.S. 361, 378 (1989) (Sentencing Commission). 
recognized as necessary in order that the exertion of legislative power does not become a futility."271 The delicate balance of interpreting the Constitution either through a functionalist versus formalist viewpoint has diffused the exact boundary of Congress' ability to delegate authority to such an extent that the Supreme Court, from early on, has been reluctant to decide on the matter unnecessarily. ${ }^{272}$ The court is more willing to sustain delegations whenever Congress provided an "intelligible principle" to which the federal agency or office could conform. ${ }^{273}$ Therefore, the Supreme Court has been very deferential to and recognizes the broad scope of Congress' ability in delegation of authority to federal agencies. ${ }^{274}$ Yet, when it comes to foreign affairs and the delegation of power to the states the court has had a more conservative approach. ${ }^{275}$

Congress has promulgated statutes delegating state officials and agencies to implement and execute federal laws. ${ }^{276}$ Although the court expressed doubts as to Congress' ability to delegate authority to the state governments, it has been more consistent in ruling that Congress can give the state government the option to enforce federal law. ${ }^{277}$ In Selective Draft Law Cases, ${ }^{278}$ the court rejected the argument that a federal statute was invalid because it delegated duties to state officers. ${ }^{279}$ Currently, the Court has reversed its position and has held in numerous occasions that state officers, by virtue of not being appointed by the President, are not federal officers possessed with the inherent power of executing federal laws. ${ }^{280}$

In Printz v. United States, ${ }^{281}$ local sheriffs sought to enjoin the enforcement of provisions of the Brady Handgun Violence Prevent Act (hereinafter "Brady

271. See Sunshine Anthracite Coal Co. v. Adkins, 310 U.S. 381, 398 (1940); See also Minstretta, 488 U.S. at 372.

272. See Wayman v. Southard, 23 U.S. 1, 42 (1825).

273. See JW Hampton Jr. \& Co. v. United States, 276 U.S. 394, 409 (1928) (legislative standards test). Since after the depression, the Supreme Court has never found a permissible Congressional delegation of power to a federal agency.

274. See, e.g., SCHOENBORD, The Delegation Doctrine: Could the Court Give it Substance?, 83 MICH. L. REV. 1223 (1985).

275. See United States v. Curtis-Wright Corp, 299 U.S. 304, 312 (1936) (sustaining a joint resolution of Congress prohibiting the sale of weapons to selected countries, upon designation by the President); Selective Draft Law Cases, 245 U.S. 366, 389 (1918). The standard practice has been to interpret narrowly the delegation so as to avoid constitutional problems.

276. See WARren, Federal Criminal Laws and the State Courts, 38 HARV. L. REv. 545 (1925).

277. See Prigg v. Pennsylvania, 41 U.S. 539 (1842).

278. Selective Draft Cases, 245 U.S. at 389.

279. See id.

280. In Printz, the Brady Gun Bill case, the court denied application of a section of the statute which delegated to local sheriffs law enforcement branches, in the interim period prior to a federal system being implemented, to enforce the federal law. 117 S.Ct. at 2383.

281. Id. at 2365 . 
Act"). The court, reaffirming New York $v$. United States, ${ }^{282}$ found that Congress could not compel states to "enact or administer a federal regulatory program."283 Provisions in the Brady Act required, inter alia, the chief law enforcement officer of a state conduct background checks in the interim period between the inception of the statute and the time the federal government scheme became operative. ${ }^{284}$ In finding the interim provisions unconstitutional, the court first addressed the government's contention that early congressional enactment supported the validity of the provisions. ${ }^{285}$ The court stated that early federal statutes did not impose an obligation to act on the state governments, instead the state authorized its courts to consent to the statute, ${ }^{286}$ or the states themselves consented to the statute. ${ }^{287}$ In addition, the court looked to the text of the Constitution $^{288}$ and concluded that "the early statutes imposing obligations on state courts [did not] imply a power of Congress to impress the state executive into its service." 289 The court eluded to the fact that the early statutes held no evidence of an explicit or implicit grant to the federal government to "command the states' executive power in the absence of a particularized constitutional authorization."290

Similarly, the ICSE provisions by requesting that state plans for child support "must . . . provide that any request for services . . . by a foreign reciprocating country or a foreign country with which the state has an arrangement described in [the other ICSE provision] shall be treated as a request by the state." 291 The Constitution in its text ${ }^{292}$ and by its structure creates a dual sovereignty, with enumerated powers vested in the federal

282. New York v. United States, 505 U.S. 144, 188 (1995).

283. Printz, 117 S.Ct. at 2383.

284. See id. at 2369.

285. See id. at 2370; See generally Bowsher v. Synar, 478 U.S. 714, 723-24 (1986) (explaining that early congressional legislation provided "'contemporaneous and weighting evidence' of the Constitution's meaning.").

286. Holgren v. United States, 217 U.S. 509, 516-17 (1910) (refusing to address the isse of "whether the states can be required to enforce [provisions of the Act of March 26, 1790] against the state's consent").

287. Printz, 117 S.Ct. at 2370; In Unites States v. Jones, 109 U.S. 513, 519-520 (1883), the court asserted that a federal statute "could not be enforced against the consent of the state." Therefore, any obligations to comply with the statute must be with the state's consent. Id.

288. U.S. CONST. art. III, § 1; U.S. CONST. art. IV, cl.2 (Supremacy Clause); U.S. CONST. art. IV, $\S 1$ (Full Faith and Credit).

289. Printz, 117 S.Ct. at 2371.

290. See id. at 2372.

291. 42 U.S.C.A. § $654 \rrbracket 32$ (A) (West 1998).

292. Lane County v. Oregon, 74 U.S. 71,76 (1869). 
government on the one hand, ${ }^{293}$ and imposed limitations upon ${ }^{294}$ and residual power ${ }^{295}$ vested in the state government on the other. ${ }^{296}$

More recently, in Condon v. Reno, ${ }^{297}$ the Court of Appeals for the Fourth Circuit held that the federal Driver's Privacy Protection Act was unconstitutional because it was a law which applied only to the states and not to private parties, thus was not a law of general applicability. ${ }^{298}$

ICSE provisions give authority to the executive branch to enter into reciprocal agreements with foreign nations, ${ }^{299}$ permits the states to enter into reciprocal agreements with foreign nations, if the federal government has not, ${ }^{300}$ and requires the states to treat foreign judgments for child support as if they originated in a sister-state. ${ }^{301}$ Thus, the effect of the statute creates a delegation to states the power to enter into agreements with foreign nations.

\section{Suggested Remedies}

The ICSE provisions can be saved by placing the issue of international child support enforcement on a completely federal level without local interference by the states in the federal government's foreign policy. By doing this, a true demarcation of authority will be defined in such a way that both sovereign powers, i.e. the state and federal governments, will not be in conflict with each other. Furthermore, the ICSE provisions can be saved without losing the desired effect by removing subsection (d) from \$659a and \$32 from $\$ 654$. These sections, which pertain to the role of the state governments in the international child support arena, as argued, weaken the statute and provides targets for non-custodial parents to challenge the statute on constitutional grounds. By enforcing the provisions and allowing Congress to do indirectly what it could not do directly, make treaties with foreign nations via the state government, Congress should consider amending the statute to include clearer legislative history illustrating what role was intended for both the federal and state governments. Finally, it is for the judiciary to decide whether to follow the Lopez precedence by finding a point to re-define that which is federal from that which is local in order to preserve the balance of federalism. On the other hand, the court may declare that those areas which are not strictly addressed by

293. U.S. CONST. art. I, \& 8.

294. See id. at art. I, § 10 .

295. See id. at amend. $X$.

296. Printz, 117 S. Ct. at 2377; Gregory v. Ashcroft, 501 U.S. 452, 457 (1991); Tafflin v. Levitt, 493 U.S. 455,458 (1990).

297. Cordon v. Reno, 155 F.3d 453 (4th Cir. 1998).

298. Id. at 456.

299. 42 U.S.C.A. $\$ 659$ a (a) (West 1998).

300. Id.

301. Id. at $\$ 654$ II 32. 
the Constitution, such as international child support enforcement, should be resolved by the democratic process of the Congressional and/or state legislature. ${ }^{302}$

\section{CONCLUSION}

As this analysis suggests, there exists sound constitutional grounds for a non-custodial parent to challenge the international child support provisions. Although federal legislature, by passing the ICSE provisions, has decided to assume a more active role in this area, they did not proceed far enough to safeguard against dismissal of claims purely on procedural grounds. If the court is expected to interpret and defer to acts of legislation, those acts should conform to the legislative intent while following the proper course of legal precedence.

The ICSE provisions reflect the federal government's enterprise in imposing extra-constitutional power upon the state governments; thus, creating an incongruity between the articulated purposes of the law and the actual content of the law itself. Furthermore, under various constitutional clauses, Congress lacks the power to delegate to states a right to enter into agreements with foreign nations. Under the Supreme Court's decision in Lopez, ${ }^{303}$ Congress has no power under the Commerce Clause to regulate family law. The content and statutory history of the ICSE provisions do not demonstrate that regulation of international child support claims substantially effect foreign commerce. Additionally, the provisions do not contain a jurisdictional element linking regulation of international child support with foreign commerce.

By granting a right to the state government to enter into agreements with foreign nations, the legislature has created a federalism problem, obscured the delicate balance between the federal and state government, and introduced ambiguity to the process of child support enforcement. By exercising control over family law, the legislature obfuscated the Supreme Court's decision in Lopez, avoiding to conservatively interpret the decision, which could have eliminated any challenge presented by unwarranted congressional abrogation of the Commerce Clause.

302. See ROBERT P. GEORGE, Justice, Legitimacy and Allegiance: The End of Democracy?, 44 LOY. L. REV. 103, 105 (1998). Justice Scalia articulated this very premise in his concurrence in Webster $v$. Reproduction Health Services, 492 U.S. 490, 523-37 (1989) (Scalia, J. concurring). Justice Scalia stated that on the issue of abortion the federal government could be neither pro-life or pro-choice since abortion, like many other things, is political in nature and not a constitutional issue. Id.

303. Lopez, 115 S. Ct. at 1624. 